\title{
Changes in parasite-chaetognath species assemblages in the Mexican Central Pacific before and during El Niño 1997-1998
}

\section{Horacio Lozano-Cobo ${ }^{1}$, Jaime Gómez-Gutiérrez ${ }^{1, *}$, Carmen Franco-Gordo ${ }^{2}$, María del Carmen Gómez del Prado-Rosas ${ }^{3}$, Viridiana Plascencia-Palomera ${ }^{2}$, Israel Ambriz-Arreola ${ }^{2}$}

\begin{abstract}
${ }^{1}$ Departamento de Plancton y Ecología Marina, Centro Interdisciplinario de Ciencias Marinas, Instituto Politécnico Nacional, Av. IPN s/n, La Paz, BCS 23096, Mexico

${ }^{2}$ Departamento de Estudios para el Desarrollo Sustentable de Zonas Costeras, Centro Universitario de la Costa Sur, Universidad de Guadalajara, Gómez Farías 82, San Patricio Melaque, Jalisco 48980, Mexico

${ }^{3}$ Laboratorio de Parasitología, Departamento Académico de Ciencias del Mar y de la Tierra, Universidad Autónoma de Baja California Sur, Apdo. Postal 19-B, La Paz, BCS 23080, Mexico
\end{abstract}

\begin{abstract}
We investigated the seasonal and interannual changes in diversity, abundance, and prevalence of chaetognaths and their parasites collected monthly during 1996-1998 in the Mexican Central Pacific. We tested the hypothesis of a positive relationship between abundance and species richness of chaetognaths and their parasites, and investigated the influence of the 19971998 El Niño event on this host-parasite interaction. Of the 9 chaetognath species collected in the present study, only 7 were found to be parasitized. Of 78154 chaetognath specimens collected, 790 were parasitized ( $1 \%$ prevalence) with at least 1 type of epibiont (cysts, perhaps protists) and 6 types of endoparasites: protists (apicomplexans, dinoflagellates, and ciliates), digeneans, cestodes, acanthocephalans, nematodes, and other unidentified endoparasites. Cysts, digeneans, and cestodes were the most abundant parasites. Mean intensity ranged from 1-4 endoparasites and from 1-21 epibionts host ${ }^{-1}$. Zonosagitta bedoti and Flaccisagitta enflata were the most abundant chaetognath species and had the highest parasite diversity. Mesosagitta minima and Parasagitta euneritica had the highest parasite prevalence ( $>2 \%)$. A 2-way cluster analysis defined sampling month groups as before, during, and after the 1997-1998 El Niño. The highest abundances of chaetognaths and parasites were associated with a high thermal stratification index, salinity, and mixed layer depth. We conclude that there is a positive, non-linear correlation between the abundance of chaetognaths and their parasites. Although El Niño decreased the abundance and diversity of chaetognaths throughout the time series, the abundance and diversity of their parasites were not significantly different among hydro-climatic periods, suggesting that host abundance must decrease orders of magnitude to influence host availability for parasites.
\end{abstract}

KEY WORDS: Protists - Platyhelminthes - Acanthocephalans - Nematodes - Larval stages · Infracommunity $\cdot$ Component community

\section{INTRODUCTION}

The taxonomy, biology, and ecology of marine helminth parasites are considerably better studied in the adult phase (infecting vertebrate definitive hosts) than in the larval stages (infecting invertebrate inter-

*Corresponding author: jgomezgu@gmail.com mediate hosts). This is partially explained because larvae typically infect in considerably lower prevalence and intensity than adult parasites (Poulin 2007), with several exceptions (Kondo et al. 2016). Additionally, taxonomic descriptions of most parasites are mostly based on the reproductive phase

(C) The authors 2018. Open Access under Creative Commons by Attribution Licence. Use, distribution and reproduction are unrestricted. Authors and original publication must be credited. 
(adults), when organisms typically possess more morphological diagnostic traits than during their early life stages. Therefore, most parasitologists begin training on relative large and common parasites from larger intermediate and definitive hosts (marine vertebrates), and may mistakenly believe that the study and discovery of parasites during their early life stages infecting marine invertebrates is complex, due to the lack of specialized taxonomic keys and difficulty of collection. However, planktonic organisms are highly abundant, and represent an immense and diverse standing stock biomass in the pelagic ecosystem of intermediate and/or paratenic hosts of parasites during the early part of their life cycles. Parasites and the host form 'holobionts,' defined as the host organism plus all of its smaller symbiotic organisms (Rosenberg et al. 2010), or infracommunities (consisting of all parasites of all species found together in 1 individual host) and the 'component community' comprising the sum of all infracommunities (Bush et al. 1997, Poulin 2007). Kamiya et al. (2014) suggested 3 universal predictors of parasite diversity across animal host species: body size, host geographical range dimensions, and host population density. Arneberg et al. (1998) and Stanko et al. (2006) also argued that the abundance of the host is an influential factor that modifies the distribution and abundance of the parasites, predicting that increased abundance of the host or the parasites increases the probability of parasite transmission to the next host. None of these universal predictors has been systematically and explicitly investigated in parasites of zooplankton.

Chaetognaths (arrow worms) are voracious holoplanktonic carnivores that prey on diverse types of zooplankton (mollusks, crustaceans, and fish larvae) and are also consumed by several zooplanktophagous predators (cephalopods, juvenile and adult fishes) (Fig. 1A). They have multiple interspecific (epibionts and parasitic) interactions that likely shape their fitness and natural selection (Fig. 1B). Thus, chaetognaths function as intermediate hosts of several trophically transmitted parasites in the pelagic ecosystem, although trophic interactions and therefore transmission processes could change ontogenetically for each zooplankton and micronekton taxonomic group (Fig. 1). Chaetognaths interact with at least 13 types of parasites; most of those types are trophically transmitted endoparasites that infect the chaetognath hosts as larvae (Lozano-Cobo et al. 2017a,b, González-Solís \& Gasca 2018). Ectoparasites and epibionts are considerably less likely to infect chaetognaths due their tegument secretions and soft body (Lozano-Cobo et al. 2017a,b). Only 3 previous studies have investigated the temporal association of chaetognath-parasite abundance. Weinstein (1972) associated abundance of the ciliate Metaphrya sagittae and the digenean Hemiurus levinseni with size class of the chaetognath Sagitta elegans in the southwestern Gulf of St. Lawrence. Daponte et al. (2008) investigated the relationship of the prevalence of several digeneans (Derogenes varicus, Ectenurus lepidus, Lepocreadiide, Monascus filiformis, and Parahemiurus merus) and tetraphyllidean metacestodes with the gonad development stage of the parasitized chaetognath Parasagitta friderici in the Mar del Plata, Argentina. In the Caribbean Sea, Lozano-Cobo et al. (2017a) estimated the abundance and average parasite:chaetognath size ratio of 33 taxa of parasites interacting with 5 chaetognath species, concluding that the parasites of chaetognaths had a considerably smaller parasite: host size ratio than those observed in zooplanktonic crustaceans. Here, we explored the population density of host chaetognaths as an ecological factor of parasite prevalence from specimens of the Mexican Central Pacific region.

Chaetognaths are abundant and have a widespread distribution. The chaetognath biogeography in the Pacific Ocean is well studied (Bieri 1959, Alvariño 1966, Ulloa et al. 2000a,b). To date, 13 studies have investigated parasitism of chaetognaths in the entire Pacific Ocean (see Table S1 in the Supplement at www.int-res.com/articles/suppl/d129p215_supp. pdf). Except for studies by Lozano-Cobo et al. (2012, 2017b) and González-Solís \& Gasca (2018), which were carried out in the Gulf of California and the Mexican Central Pacific (Mexico), the rest of the studies in the Pacific Ocean were conducted in Japan and China (Table S1). Prevalence and intensity of parasites associated with chaetognaths have been systematically studied only in 2 monthly zooplankton time series carried out in the North Pacific. The first study monitored the apostome ciliate Vampyrophrya pelagica, which infests copepods that are preyed upon by chaetognaths (Ohtsuka et al. 2004). The second study was the discovery of acanthocephalans infecting 3 species of chaetognaths during a 19961998 zooplankton time series carried out over the continental shelf of the Mexican Central Pacific (Lozano-Cobo et al. 2017b) (Table S1). The present study reports all parasites found in chaetognaths from this 1996-1998 tropical zooplankton time series. Ambriz-Arreola et al. (2012) defined 3 seasonal hydro-climatic periods in the Mexican Central Pacific (1996-1998) based on the thermo-haline properties 


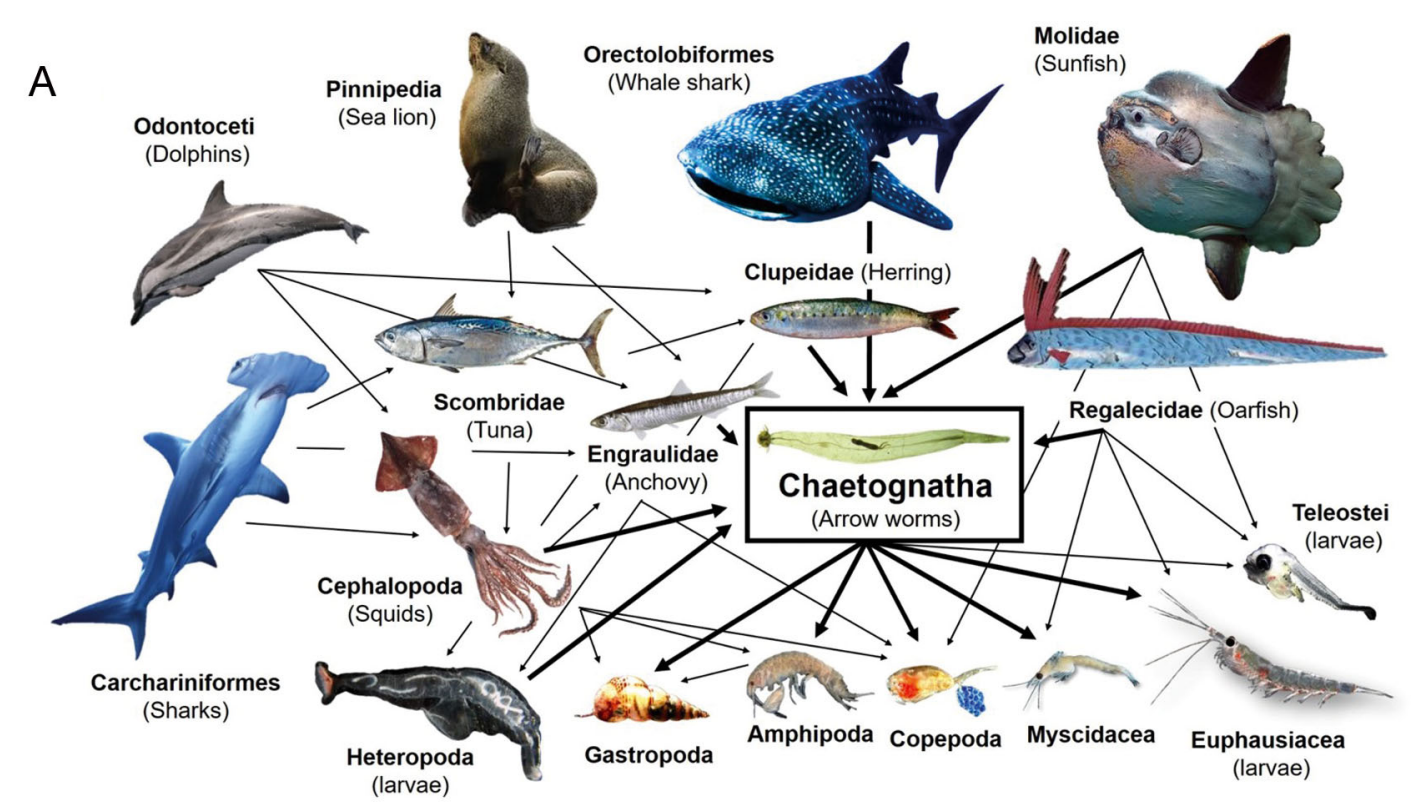

B Chaetognaths (parasitized)

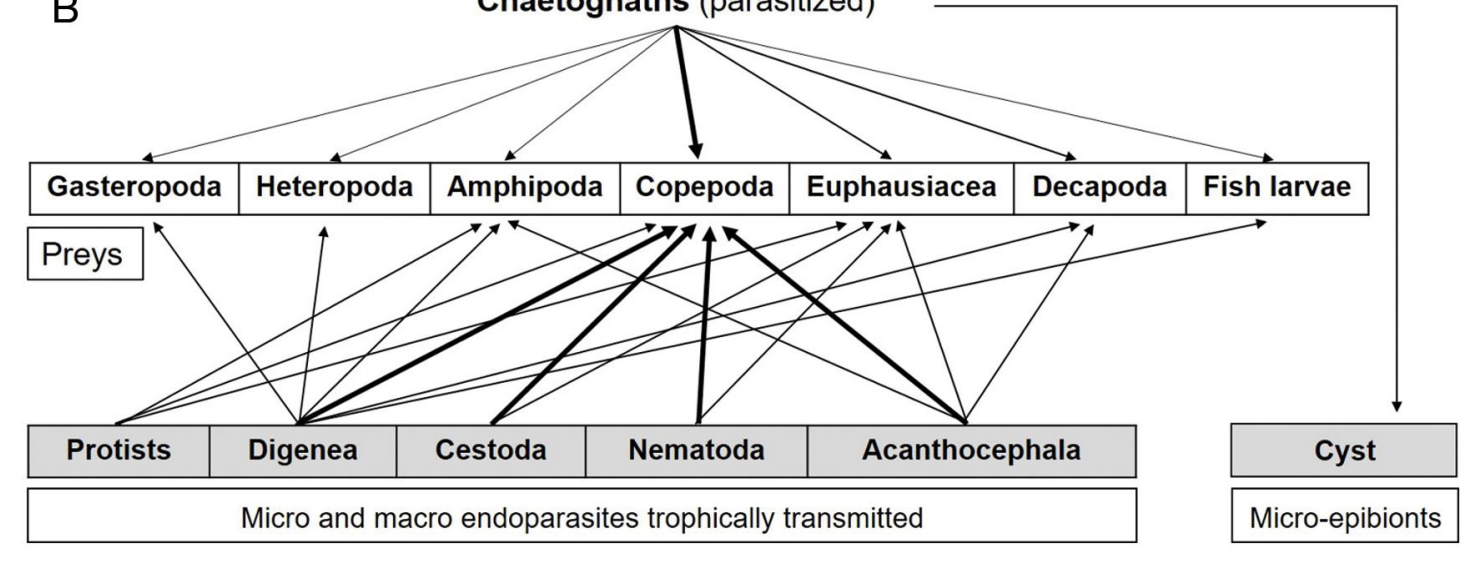

Types of symbionts (parasites or epibionts)

Fig. 1. (A) Conceptual model of chaetognath interspecific interactions in marine tropical pelagic ecosystem with prey (most of which are likely to become infected by trophic transmission of endoparasites) and predators (that likely transmit endoparasites to higher trophic levels). (B) Micro-epibionts and parasites (shaded grey boxes) and preys (empty boxes) known to interact with chaetognaths in the region of study. Bold lines indicate more frequent and direct trophic or symbiotic interactions and the arrows point from predators toward preys or from parasites toward the host

recorded in the entire water column: mixed (FebruaryMay), semi-mixed (transitional, December-January and June), and stratified (July-November) periods. They also delimited the regionally anomalous warm influence of the 1997-1998 El Niño event occurring between May 1997 and May 1998.

The oceanographic and climatic conditions which occurred during El Niño 1997-1998 have been previously studied in the Pacific Ocean (Lavaniegos et al. 2002, 2006, Palma \& Aravena 2002, Naranjo 2009, Godínez et al. 2010, Ambriz-Arreola et al. 2012). The 1996-1998 monthly zooplankton time series was previously analyzed to investigate temporal variability in the abundance of fish larvae, euphausiids, amphipods, and copepods (Franco-Gordo et al. 2002, 2003, 2004, Ambriz-Arreola et al. 2012, Gasca et al. 2012, Kozak et al. 2014).

We tested 2 hypotheses in the present study: (1) the standardized abundance (ind. $\mathrm{m}^{-3}$ ) and prevalence $(\%)$ of parasites have a positive relationship with the diversity and standardized abundance of the chaetognath host species; (2) the brief but strong El Niño of 1997-1998 induced warm and unproductive environmental conditions that promoted shifts in chaetognath species assemblages, negatively influencing the diversity, abundance, 
and prevalence of their parasites. This study had 2 main goals: (1) quantitatively investigate the relationship between standardized abundance, diversity, and prevalence (\%) of the chaetognath hosts and their parasites, and (2) investigate the seasonal and interannual changes in abundance, diversity, prevalence, and mean intensity of parasites of chaetognaths as a function of environmental conditions that prevailed before and during the strong but brief 1997-1998 El Niño event along the inshore region of the Mexican Central Pacific. This monthly and systematic time series provides the first quantitative information about host-parasite interactions as a function of environmental conditions prevailing in the Eastern Tropical Pacific. Results from the present study were compared with the only other tropical latitude chaetognath-parasite time series, carried out off the Yucatan peninsula (Caribbean Sea) (Lozano-Cobo et al. 2017a).

\section{MATERIALS AND METHODS}

\section{Field sampling}

The Mexican Central Pacific continental shelf was sampled in 2 evenly spaced transects parallel to the coast covering an area of $\sim 33 \mathrm{~km}^{2}$ located over the

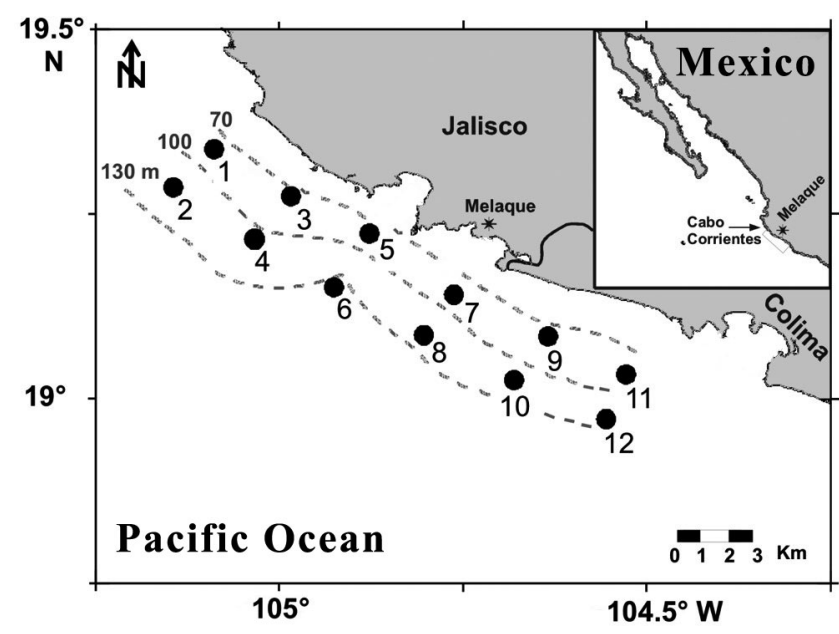

Fig. 2. Zooplankton sampling stations $(n=12)$ visited during 26 monthly oceanographic cruises carried out along the continental shelf of the Mexican Central Pacific between January 1996 and December 1998. Seafloor depth contours indicated for 70,100 , and $130 \mathrm{~m}$ isobaths. The interactions between water masses and seasonal patterns of circulation of the Mexican Coastal Current (MCC), the tropical branch of the California Current, and the flows through the entrance of the Gulf of California are explained in detail by Portela et al. (2016) continental shelf along the coast from Jalisco to Colima states, Mexico (Fig. 2). Twelve oceanographic stations were sampled during 26 monthly oceanographic cruises carried out between January 1996 and December 1998. The time series had several temporal gaps in 1996 (August, September), 1997 (April-June, October, November), and 1998 (February, October, November) due to unfavorable climatic conditions (hurricane season) or other logistical problems. Vertical profiles of temperature $\left({ }^{\circ} \mathrm{C}\right)$ and salinity were recorded at each oceanographic station using a CTD SeaBird (SB09) (recording $~ 10 \mathrm{~m}$ above the seafloor $<100 \mathrm{~m}$ ). A total of 146 zooplankton samples were collected at night (between sunset and sunrise, seasonally changing period) with a standard bongo zooplankton net $(61 \mathrm{~cm}$ mouth diameter, $505 \mu \mathrm{m}$ mesh net) by oblique tows at $<0.5 \mathrm{~m} \mathrm{~s}^{-1}$ speed from $10 \mathrm{~m}$ above the sea floor to the surface. A calibrated digital flowmeter (General Oceanics model 2030R6) was attached to the mouth of each plankton net to estimate the volume of water filtered by the net during each tow (Smith \& Richardson 1977). Each zooplankton sample was preserved in $4 \%$ formalin $(\mathrm{pH}$ neutralized with saturated solution of sodium borate).

\section{Morphological identifications}

All chaetognath specimens sorted out from the entire zooplankton samples were identified using standard taxonomic keys (Alvariño 1963, 1965, Bieri 1991a,b) and counted. Each chaetognath specimen was examined under an optical stereoscope (Carl Zeiss SV11) for any of the 13 types of pathogen, epibiont, parasite, and/or micro-predators known to infect chaetognaths (Lozano-Cobo et al. 2017a,b). Parasitized chaetognaths were gradually dehydrated in a series of ethanol solutions from 30 to $96 \%$ concentration and stained with Gömöri trichrome (Salgado-Maldonado 1979). Additionally, parasitized chaetognaths were made transparent with clove oil and mounted in synthetic resin (in $60 \%$ xylene) on permanent slides to observe the external and internal morphological characteristics of each parasite with a compound microscope (Leica DMLB). Parasites of chaetognaths were identified using specialized taxonomic keys for adult parasites (Yamaguti 1959, 1961, 1971, Anderson et al. 1975, Chabaud 1975, Khalil et al. 1994, Gibson 2002a,b, Gibson et al. 2002, Bray 2005, Jones et al. 2005, Bray et al. 2008) and taxonomic information from previous studies carried out in different regions of the world (Dawes 
1959, Shimazu 1978, 1982, Pierrot-Bults 1990, Nagasawa 1991, Gómez del Prado-Rosas et al. 1999a,b, 2000, 2002, 2005, 2007, Ohtsuka et al. 2004, Øresland \& Bray 2005, Coats et al. 2008, Daponte et al. 2008, Lozano-Cobo et al. 2012, 2017a,b). The diagnostic morphological features of each parasite reported in all previously mentioned references are summarized in Table S2 in the Supplement. Parasitized chaetognaths and their parasites were measured and photographed with a digital camera (Canon Power Shot A2500). Molecular analysis was not performed because all zooplankton samples collected during the 1996-1998 monthly time series were preserved in $4 \%$ formalin. External morphological characteristics of 2 or 3 specimens of the most abundant taxa of parasites were observed with a scanning electron microscope (SEM). Each specimen was gradually dehydrated in an ethanol series $(70,80,96 \%)$ and critical point dried with $\mathrm{CO}_{2}$ (Polaron E3000). Specimens were later coated with gold (Polaron E5100) and observed using an SEM (Hitachi S-3000N) at $20 \mathrm{kV}$. All SEM images were digitally edited using Photoshop to improve brightness/contrast and add their respective size scales $(\mu \mathrm{m})$.

\section{Data reduction and statistical methods}

Total abundance of each chaetognath species and each parasitized chaetognath species (per type of parasite) was standardized to number of ind. $\mathrm{m}^{-3}$ (Smith \& Richardson 1977). Mean \pm SD abundance was calculated per month (using the 12 sampling stations as replicates) and per year (using the 12 monthly averages) to compare temporal abundance throughout the entire time series. We estimated mean abundance of parasitized chaetognaths according to criteria detailed by Morales-Ávila et al. (2015) and Lozano-Cobo et al. (2017a,b). Prevalence (percentage of parasitized chaetognaths per species from the total of each chaetognath species observed in the entire zooplankton sample) and mean intensity (number of the same type of parasites per host specimen) were estimated following the criteria of Bush et al. (1997). Prevalence of all parasites of each chaetognath species was also averaged per month (using the 12 stations as replicates) and per year to analyze seasonal and interannual variability throughout the time series.

Temporal associations using abundance of chaetognaths, parasitized chaetognaths, and parasites were explored as a function of the monthly means (n = 3-12 stations per sampling month) of 5 envi- ronmental variables using non-parametric statistical exploratory methods: (1) multivariate ENSO index (MEI, https://www.esrl.noaa.gov/psd/enso/ mei/), (2) Southern Oscillation index (SOI, https:// crudata.uea.ac.uk/cru/data/soi/), (3) the daily coastal upwelling index (CUI, https://www.pfeg.noaa.gov/ products/PFEL/modeled/indices/upwelling/NA/data _download.html) calculated on the day of zooplankton sampling (CUIsam) and $8 \mathrm{~d}$ before each zooplankton sampling event (CUIsam-8), (4) the mixed layer depth (MLD) comprising the layer between surface and the upper limit of the thermocline, and (5) the thermal stratification index (TSI) as previously defined by Ambriz-Arreola et al. (2012). We created 2 distinct abundance matrices: (1) the 9 chaetognath species recorded in the present study (columns) collected during 25 sampling months (rows) and (2) the 7 parasitized chaetognath species plus 7 types of parasites (columns) collected during 22 sampling months (rows). Each abundance matrix had a corresponding environmental matrix, which included the following oceanographic variables: TSI, temperature at $10 \mathrm{~m}$ depth $\left(\mathrm{T}_{10 \mathrm{~m}}\right)$, salinity at $10 \mathrm{~m}$ depth $\left(\mathrm{S}_{10 \mathrm{~m}}\right)$, MLD, the daily CUI calculated on the day of zooplankton sampling $\left(\mathrm{CUI}_{\text {sam }}\right)$ and $8 \mathrm{~d}$ before each sampling event $\left(\mathrm{CUI}_{\mathrm{sam}-8}\right)$, and mean monthly $\mathrm{CUI}$ as defined by Ambriz-Arreola et al. (2012). These 2 environmental matrices also included 3 temporal categorical variables: (1) mixed (February-May), semimixed (December-January and June), stratified (July-November), hydro-climatic periods defined by Ambriz-Arreola et al. (2012), (2) before (January 1996-April 1997) and after (June-December 1998) the 1997-1998 El Niño, and (3) the years 1996, 1997, and 1998. All abundances were $\log (x+1)$ transformed to decrease the variance of the data set (McCune et al. 2002). The abundance and species richness of all chaetognath species, parasitized chaetognaths, and types of parasites per sampling station were plotted as a function of sampling month through 1996-1998 in contour maps using Golden Surfer (V12) software.

A 2-way cluster analysis (CA), using the Sorensen distance measure and $\beta$-flexible linkage method $(\beta=$ 0.25 ), defined zooplankton sampling groups based on monthly average abundance similarities of the chaetognath and parasite species (Field et al. 1982, McCune et al. 2002), followed by a multi-response permutation procedure (MRPP) to test for statistically significant differences in abundance among the groups. A non-metric multi-dimensional scaling (NMDS) technique was carried out to compare the distribution and abundance of all chaetognath spe- 
cies, parasitized chaetognath species, and types of parasites as a function of environmental variables. The NMDS shows temporal bi-plot ordination of monthly sampling units and abundance of chaetognaths and parasitized chaetognaths (per parasite type). The vectors indicate the direction of the environmental gradients, and the length of the vectors represents the relative contribution of each variable to total observed variance (Ter Braak 1986). Indicator species analysis (ISA) was used to detect which chaetognath and/or parasite species were good indicators for each cluster-defined group. The ISA method measures the abundance and relative frequency of a species in a particular group as defined by a null hypothesis. The highest ISA value for each species was tested for statistical significance using a Monte Carlo randomization technique (Dufrene \& Legendre 1997, McCune et al. 2002). The ISA values range from 0 (no indication) to 100 (perfect indication). Perfect indication means that presence of a particular chaetognath species or parasite type points to a particular environmental monthly group without error. Because all of these statistical analyses are non-parametric statistical tests, it was not necessary to assume that abundances and environmental variables were normally distributed (McCune et al. 2002). All non-parametric statistical exploratory analyses were performed using PC-ORD 6.0 software Multivariate Analysis of Ecological Data (McCune et al. 2002) (MjM Software). A non-parametric ANOVA Kruskal-Wallis rank test $(\mathrm{p}<0.01$, Statistica 7.0 software) was done to test whether significant differences existed in the community structure of the chaetognath abundances and parasitized chaetognath abundances among climatic periods. In order to analyze the specific sample pairs for stochastic dominance in post hoc testing, a pairwise MannWhitney $U$-test without Bonferroni correction was done.

\section{RESULTS}

\section{Parasite diversity}

The component community of the parasites that interacted with chaetognaths during the entire study period included 28 distinct taxa identified morphologically to different taxonomic levels (Fig. 3, Tables 1 \& S2). Cysts, protist sp. 2, the digenean Monilicaecum larval type, and the cestode Tetraphyllidea sp. 2 were the most abundant types of parasites during the entire zooplankton time series. All platyhelminthes (digeneans and cestodes), nematodes, and acanthocephalans were found in larval stages (Table 1). The cysts and protists were observed at more than one life stage (Figs. 3A-C \& 4A-E). Because the mean abundance of each parasite taxon was very low, we combined parasite abundances based on the phylum or class level to infer their seasonal and interannual changes using multivariate analyses (Table 2).

Diagnostic morphological features used to identify each type of parasite are summarized in Table S2. Unidentified cysts (likely of protists) were observed attached to the external tegument of the chaetognaths and infecting the hemocoel of the trunk cavity, intestine, and head of Zonosagitta bedoti (Fig. 3A-C). Six types of protists (apicomplexan, dinoflagellate, and ciliate) infected the intestine and trunk cavity of chaetognaths (Fig. 3D-I). Several types of digenean larvae infected the intestine, trunk, and caudal cavity of several chaetognath species: Digenea type 1 (Fig. 3J); Cercaria owreae (Fig. 3K), Accacoelidae sp. 1 (Fig. 3L); Accacoelidae sp. 2 (Fig. 3M); Didymozoidae sp. 1 (Fig. 3N); Monilicaecum larval type (Fig. 3O); Paratorticaecum larval type (Fig. 3P); Hemiuridae sp. 1 (Fig. 3Q); Parahemiurus sp. (Fig. 3R); Brachyphallus sp. (Fig. 3S), and Lepocreadiidae (Fig. 3T). Six types of larval cestodes from the order Tetraphyllidea infected the trunk cavity of chaetognaths (Fig. 3U-Z); 1 larval nematode of Contracaecum sp. (L3 larval stage) infected the trunk cavity (Fig. 3Ab); and larval cystacanth acanthocephalan Corynosoma sp. parasitized 3 chaetognath species (Fig. 3Ac). Two unidentified parasites were also observed infecting the intestine and trunk cavity (Fig. 3Ad, Ae).

External morphology of 9 of the 28 taxa of parasites shown in Fig. 3 was also observed using SEM (Fig. 4A-Q). We observed the possible ontogenetic development of one type of cyst attached as an epibiont on the external tegument and head of Zonosagitta bedoti (Fig. 4A-E). The helminths observed with SEM (Fig. 4) were the digenean trematode Cercaria owreae infecting the trunk cavity of Flaccisagitta enflata (Fig. 4F,G); the digenean Accacoelidae sp. 1 infecting the trunk cavity of F. enflata (Fig. 4H); the digenean Hemiuridae sp. 1 infecting the caudal cavity of $Z$. bedoti (Fig. 4I,J); the digenean hemiurid Parahemiurus sp. infecting the trunk cavity of $F$. enflata (Fig. 4K); the digenean hemiurid Brachyphallus sp. infecting the caudal cavity of $Z$. bedoti (Fig. $4 \mathrm{~L}$ ); a larval cestode of the order Tetraphyllidea sp. 2 infecting the trunk cavity of $F$. hexaptera (Fig. 4M); a larval cestode of the order Tetraphyllidea sp. 3 infect- 

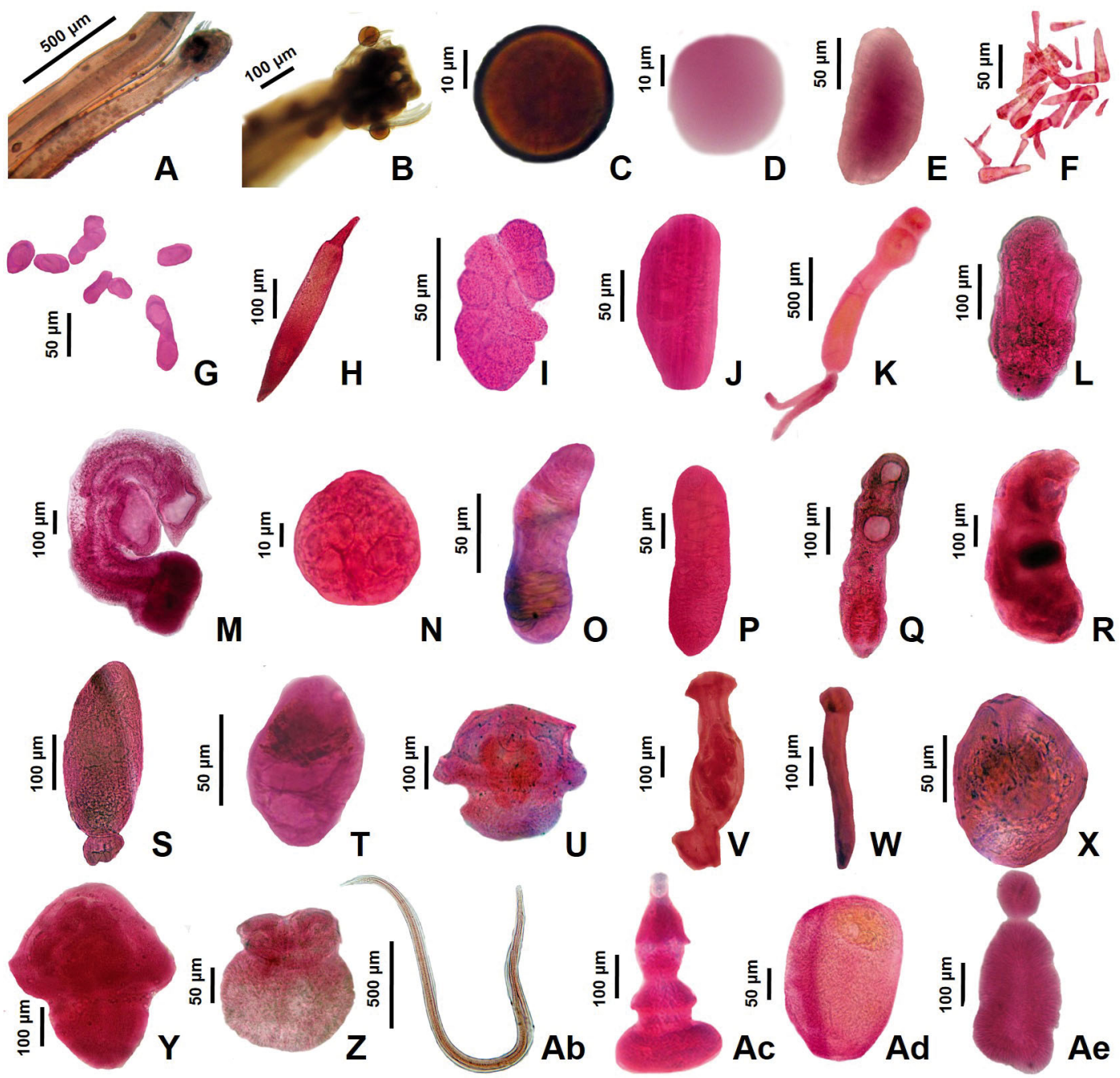

Fig. 3. Photographs of the 26 taxa of parasites plus 2 unidentified symbionts that interact with chaetognaths collected monthly during 1996-1998 along the continental shelf of the Mexican Central Pacific. (A-C) Unidentified epibiont cysts infesting Zonosagitta bedoti. (D-I) Protists (including ciliates and apicomplexans). (J) Digenea type 1. (K) Cercaria owreae. (L) Accacoelidae sp. 1. (M) Accacoelidae sp. 2. (N) Didymozoidae sp. 1. (O) Monilicaecum larval type. (P) Paratorticaecum larval type. (Q) Hemiuridae sp. 1. (R) Parahemiurus sp. (S) Brachyphallus sp. (T) Lepocreadiidae sp. (U-Z) larval stages of cestodes of the order Tetraphyllidea. (Ab) Nematode larva (stage L3) of Contracaecum sp. (Ac) Cystacanth acanthocephalan of Corynosoma sp. (Ad,Ae) 2 unidentified symbionts

ing the trunk cavity of F. enflata (Fig. 4N); and the larval (stage L3) nematode Contracaecum sp. infecting the trunk cavity of $F$. enflata (Fig. 4O-Q). The acanthocephalan SEM images were reported by Lozano-Cobo et al. (2017b) and are not shown here.

\section{Community structure of the chaetognaths and their parasites}

Nine chaetognath species were identified from a total of 78154 chaetognath specimens collected during the monthly zooplankton time series (Table 3). The mean abundance of all species showed 2 peaks in the time series (January-October 1996 with $<40$ ind. $\mathrm{m}^{-3}$ and July 1997-March 1998 with $<30$ ind. $\mathrm{m}^{-3}$ ) (Fig. 5A). The maximum total chaetognath abundance was observed in June 1996, and included 6 of the 9 chaetognath species identified (Fig. 5B). Prevalence of parasitized chaetognaths had a similar pattern of abundance throughout the time series (peaking during January-July 1996 and during and after the El Niño event, July 1997-September 1998). However, parasitized chaetognath abundance was just $5 \%$ of the total chaetognath abundance (Fig. 5A,C). The mean prevalence was considerably higher during January-June 1996 $(80 \%)$ than during the rest of the time series 
Table 1. Taxonomic classification of the 28 taxa of parasites of chaetognaths, parasite life stage, total number of parasites, and annual mean abundance (ind. $\mathrm{m}^{-3}$ ) of each parasite collected during the 1996-1998 zooplankton time series along the continental shelf of the Mexican Central Pacific. TMA: total mean abundance

\begin{tabular}{|c|c|c|c|c|c|c|c|c|c|}
\hline \multirow[t]{2}{*}{$\begin{array}{l}\text { Type of } \\
\text { parasite }\end{array}$} & \multirow[t]{2}{*}{$\begin{array}{l}\text { Classification of } \\
\text { parasite }\end{array}$} & \multirow[t]{2}{*}{ Parasite life stage } & \multicolumn{3}{|c|}{$\begin{array}{l}\text { Total of parasites } \\
\text { analyzed }\end{array}$} & \multicolumn{3}{|c|}{$\begin{array}{l}\text { Annual mean } \\
\text { abundance }\end{array}$} & \multirow[t]{2}{*}{ TMA } \\
\hline & & & 1996 & 1997 & 1998 & 1996 & 1997 & 1998 & \\
\hline Cyst & Cyst & - & 831 & 16 & 231 & 0.796 & 0.031 & 0.258 & 1.086 \\
\hline Protist & Protist sp. 1 (Apicomplexa) & - & 7 & 3 & 2 & 0.007 & 0.001 & 0.001 & 0.009 \\
\hline Protist & Protist sp. 2 & - & 0 & 100 & 0 & 0 & 0.133 & 0 & 0.133 \\
\hline Protist & Protist sp. 3 (Ciliata) & - & 2 & 0 & 0 & 0.002 & 0 & 0 & 0.002 \\
\hline Protist & Protist sp. 4(Dinoflagellata) & - & 1 & 0 & 0 & 0.001 & 0 & 0 & 0.001 \\
\hline Protist & Protist sp. 5 (Ciliata) & - & 20 & 1 & 1 & 0.022 & 0.002 & 0.002 & 0.026 \\
\hline Protist & Protist sp. 6 (Apicomplexa) & - & 1 & 0 & 0 & 0.001 & 0 & 0 & 0.001 \\
\hline Digenea & Digenea type 1 & Metacercariae & 1 & 17 & 2 & 0.001 & 0.027 & 0.003 & 0.031 \\
\hline Digenea & Cercaria owreae & Cercariae & 3 & 10 & 10 & 0.003 & 0.017 & 0.013 & 0.033 \\
\hline Digenea & Accacoelidae sp. 1 & Metacercariae & 0 & 18 & 5 & 0 & 0.026 & 0.008 & 0.034 \\
\hline Digenea & Accacoelidae sp. 2 & Metacercariae & 1 & 14 & 1 & 0.001 & 0.021 & 0.001 & 0.023 \\
\hline Digenea & Didymozoidae sp. 1 & Metacercariae & 19 & 6 & 2 & 0.018 & 0.010 & 0.003 & 0.031 \\
\hline Digenea & Monilicaecum larval type & Metacercariae & 160 & 26 & 12 & 0.157 & 0.041 & 0.016 & 0.215 \\
\hline Digenea & Paratorticaecum larval type & Metacercariae & 0 & 1 & 1 & 0 & 0.002 & 0.001 & 0.003 \\
\hline Digenea & Hemiuridae sp. 1 & Metacercariae & 20 & 1 & 5 & 0.021 & 0.002 & 0.007 & 0.031 \\
\hline Digenea & Parahemiurus sp. & Metacercariae & 7 & 0 & 0 & 0.009 & 0 & 0 & 0.009 \\
\hline Digenea & Brachyphallus sp. & Metacercariae & 2 & 0 & 0 & 0.002 & 0 & 0 & 0.002 \\
\hline Digenea & Lepocreadiidae sp. & Metacercariae & 0 & 0 & 1 & 0 & 0 & 0.002 & 0.002 \\
\hline Cestoda & Tetraphyllidea sp. 1 & Plerocercoid & 7 & 4 & 3 & 0.009 & 0.007 & 0.003 & 0.020 \\
\hline Cestoda & Tetraphyllidea sp. 2 & Plerocercoid & 31 & 28 & 24 & 0.029 & 0.057 & 0.031 & 0.116 \\
\hline Cestoda & Tetraphyllidea sp. 3 & Plerocercoid & 9 & 2 & 2 & 0.009 & 0.003 & 0 & 0.013 \\
\hline Cestoda & Tetraphyllidea sp. 4 & Plerocercoid & 5 & 11 & 2 & 0.005 & 0.018 & 0.001 & 0.024 \\
\hline Cestoda & Tetraphyllidea sp. 5 & Plerocercoid & 6 & 0 & 0 & 0.007 & 0 & 0 & 0.007 \\
\hline Cestoda & Tetraphyllidea sp. 6 & Plerocercoid & 0 & 1 & 0 & 0.001 & 0.002 & 0 & 0.003 \\
\hline Acanthocephala & Corynosoma sp. & Cystacanth & 4 & 2 & 6 & 0.005 & 0.003 & 0.007 & 0.014 \\
\hline Nematoda & Contracaecum sp. & Larva 3 & 4 & 0 & 3 & 0.005 & 0 & 0.005 & 0.010 \\
\hline Symbiont & Symbionts sp. 1 & - & 2 & 0 & 0 & 0.002 & 0 & 0 & 0.002 \\
\hline Symbiont & Symbionts sp. 2 & - & 0 & 14 & 0 & 0 & 0.034 & 0 & 0.034 \\
\hline Total & & & 1143 & 275 & 313 & 0.931 & 0.256 & 0.211 & 1.398 \\
\hline
\end{tabular}

Table 2. Number of parasitized chaetognath specimens analyzed per type of parasite, prevalence, number, and mean intensity of each type of parasite per year collected during 1996-1998 along the continental shelf of the Mexican Central Pacific. Number of chaetognath specimens analyzed per year: $1996=37119 ; 1997=19713 ;$ and $1998=21322$

\begin{tabular}{|c|c|c|c|c|c|c|c|c|c|c|c|c|}
\hline \multirow[t]{2}{*}{ Type of parasite } & \multicolumn{3}{|c|}{ Parasitized chaetognaths } & \multicolumn{3}{|c|}{ Prevalence (\%) } & \multicolumn{3}{|c|}{ No. of parasites } & \multicolumn{3}{|c|}{ Mean intensity } \\
\hline & 1996 & 1997 & 1998 & 1996 & 1997 & 1998 & 1996 & 1997 & 1998 & 1996 & 1997 & 1998 \\
\hline Cyst & 244 & 4 & 50 & 0.66 & 0.02 & 0.23 & 820 & 16 & 229 & 3.4 & 4 & 4.6 \\
\hline Protist & 17 & 5 & 3 & 0.05 & 0.03 & 0.01 & 25 & 104 & 3 & 1.5 & 20.8 & 1 \\
\hline Digenea & 193 & 88 & 39 & 0.52 & 0.45 & 0.18 & 219 & 93 & 39 & 1.1 & 1 & 1 \\
\hline Cestoda & 50 & 42 & 31 & 0.13 & 0.21 & 0.15 & 58 & 45 & 31 & 1.2 & 1.1 & 1 \\
\hline Acanthocephala & 4 & 0 & 6 & 0.01 & 0 & 0.03 & 4 & 0 & 6 & 1 & 0 & 1 \\
\hline Nematoda & 4 & 2 & 3 & 0.01 & 0.01 & 0.01 & 4 & 2 & 3 & 1 & 1 & 1 \\
\hline Unidentified symbiont & 2 & 3 & 0 & 0.01 & 0.02 & 0 & 2 & 7 & 0 & 1 & 2.3 & 0 \\
\hline Total & 514 & 144 & 132 & 1.38 & 0.73 & 0.62 & 1132 & 267 & 311 & 2.2 & 1.8 & 2.36 \\
\hline
\end{tabular}

(Fig. 5C). F. enflata (22.5 ind. $\mathrm{m}^{-3}$ ) and $Z$. bedoti (29.7 ind. $\mathrm{m}^{-3}$ ) were the most abundant non-parasitized and parasitized chaetognath species during 1996-1998 (Figs. 5D \& 6G,H).

All chaetognath species were collected during the 3 sampling years, except Aidanosagitta neglecta (collected only during January-March 1996; Fig. 6A), Mesosagitta minima (absent during 1998 Fig. 6B), and Serratosagitta pseudoserratodentata (collected only during February 1996; not shown). A. neglecta, M. minima, S. pacifica, and S. pseudoserratodentata had the lowest abundances (Fig. 6A-F, Table 3). All 
Fig. 4. Scanning electron micrographs showing external morphological structures of 9 frequent types of parasites of chaetognaths collected monthly during 1996-1998 along the continental shelf of the Mexican Central Pacific. (A-E) Epibiont cysts (arrows) at different development phases infesting the chaetognath Zonosagitta bedoti. (F) Ventral and (G) dorsal views of the digenean trematode Cercaria owreae. Ventral views of $(\mathrm{H})$ the digenean trematode Accacoelidae sp. 1., $(\mathrm{I}, \mathrm{J})$ the digenean Hemiuridae sp. 1., (K) the digenean hemiurid Parahemiurus sp., and (L) the hemiurid Brachyphallus sp. $(\mathrm{M}, \mathrm{N})$ Larval cestodes of the order Tetraphyllidea sp. 2. and sp. 3, respectively. (O) Nematode larva (stage L3) of Contracaecum sp., with magnified images of the (P) anterior and

(Q) posterior part of the nematode body
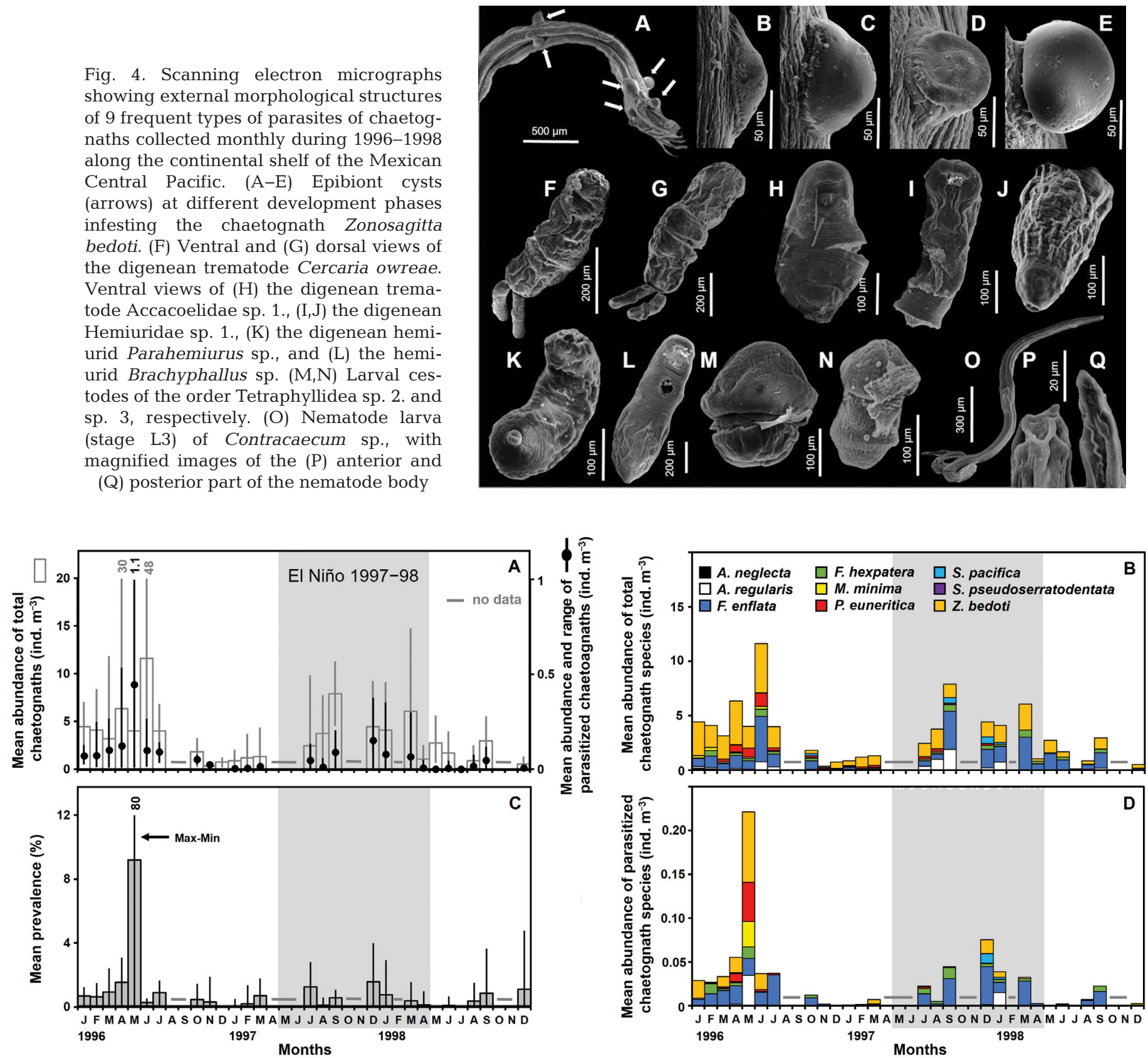

Fig. 5. Temporal variability of (A) mean abundance of total chaetognaths and mean and range (maximum to minimum) abundances of parasitized chaetognaths; and (B) separated per species; (C) mean prevalence combining all types of parasites from all parasitized chaetognath species; and (D) mean abundance of total chaetognaths separated per species collected monthly during 1996-1998 along the continental shelf of the Mexican Central Pacific

chaetognath species were infected with at least 1 type of parasite, except A. neglecta and S. pseudoserratodentata (Fig. 6A-H) (the latter is not shown). A total of 790 chaetognath specimens were observed parasitized with at least 1 type of parasite. The overall mean prevalence of parasites of chaetognaths was $1 \%$ (combining all zooplankton samples) (Table 2). The abundance of each parasite type was low and heterogeneously distributed across the chaetognath community, but when combined per taxonomic class or order, they were frequent during the entire time series. The mean abundance of parasites was higher when the mean total abundance of each chaetognath species was high (Fig. 6A-H, Table 4). F. enflata (1996) and $F$. hexaptera (1996-1997) were the only species which interacted with all types of parasites 


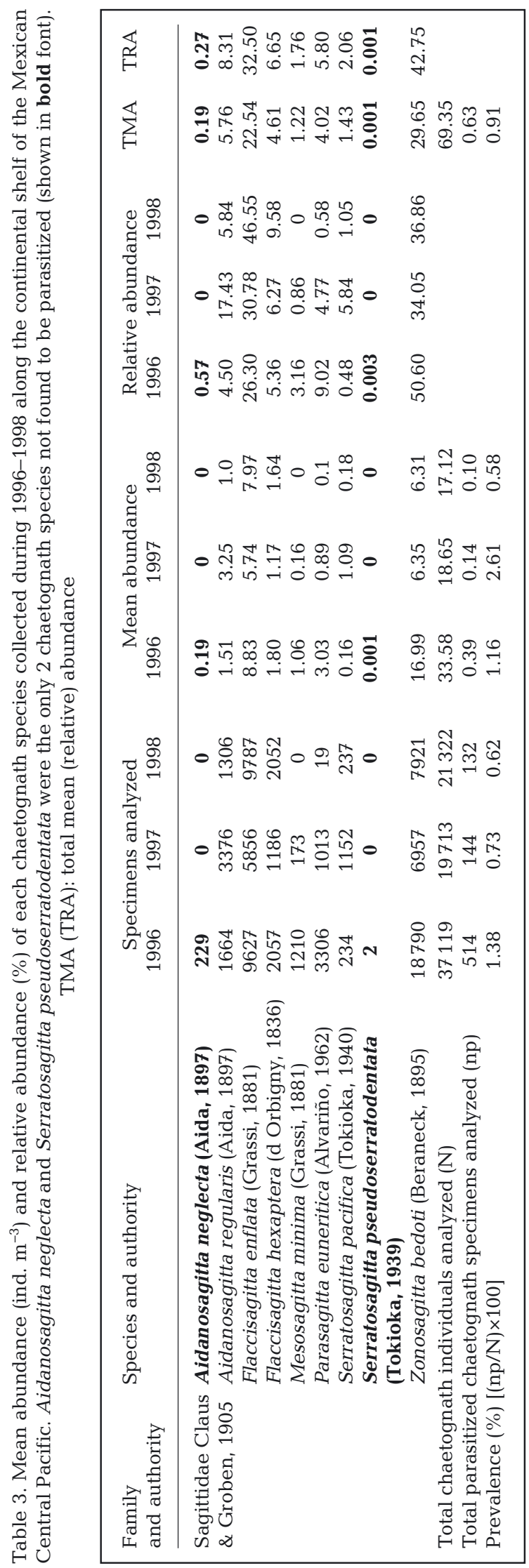

over the entire study period (Table 4). However, abundance of the numerically dominant types of parasites and parasitized chaetognath species varied among years. The cysts were the most abundant and prevalent parasites, infecting M. minima, A. regularis, $P$. euneritica, and $Z$. bedoti during 1996, and $F$. hexaptera, A. regularis, and F. enflata during 1998 (Fig. 6B-H, Table 4). The protists that infected F. enflata were the most abundant parasites during 1997. Cestodes were observed during the 3 years infecting 5 chaetognath species $(F$. enflata, $F$. hexaptera, P. euneritica, S. pacifica, and $Z$. bedoti). Acanthocephalans were observed during the 3 years parasitizing $F$. enflata, $F$. hexaptera, and $Z$. bedoti. Nematodes were observed infecting $F$. enflata and $F$. hexaptera during 1996 and 1998. The other symbionts occurred infecting $A$. regularis and F. enflata during 1996 and $F$. enflata and $F$. hexaptera during 1996-1997 (Fig. 6B-H, Table 4). The monthly and interannual variability of mean abundance of parasites showed the highest diversity between JanuaryOctober 1996 and July 1997-March 1998 (El Niño event). The cysts and the digenean trematodes were the most abundant parasites observed during January-October 1996, and protists, digeneans, and cestodes were the most abundant parasites observed during July-March 1998 (Fig. 6B-H).

The abundance of all chaetognath species combined as a function of sampling stations located along the 2 transects (near the coast and far from the coast) and months was relatively high at locations near the coast (Stations [Stns] 3, 5, 7, and 9) during April-June 1996 (14.8-47.6 ind. $\mathrm{m}^{-3}$; Fig. 7A). The abundance of all chaetognath species combined was significantly higher before and during El Niño (May 1997-May 1998) than during the post-El Niño period (JuneDecember 1998) $(H=34, \mathrm{p}<0.001$, ANOVA KruskalWallis rank test). The rank sum of total abundance was significantly higher before than during El Niño 1997-1998, and the lowest abundance was recorded after El Niño (Mann-Whitney $U$-test, $\mathrm{p}<0.002$ ). The abundance of parasitized chaetognath species was relatively high at Stns 4 and 5 during May 1996 (0.9-1.1 ind. $\mathrm{m}^{-3}$; Fig. 7B). The abundance of all types of parasites combined was very low $\left(<0.5\right.$ ind. $\left.\mathrm{m}^{-3}\right)$, with relatively low variability throughout the time series (Fig. 7C). The highest abundance of all types of parasites was recorded at Stn 5 (located near the coast) during May 1996 (6.8 ind. $\mathrm{m}^{-3}$ ) (Fig. 7C).

Stn 7 was the only sampling station with 8 chaetognath species (February 1996) (Fig. 7D). Chaetognath species richness was highest (7-9 spp.) during January-July 1996, January-March, and July- 

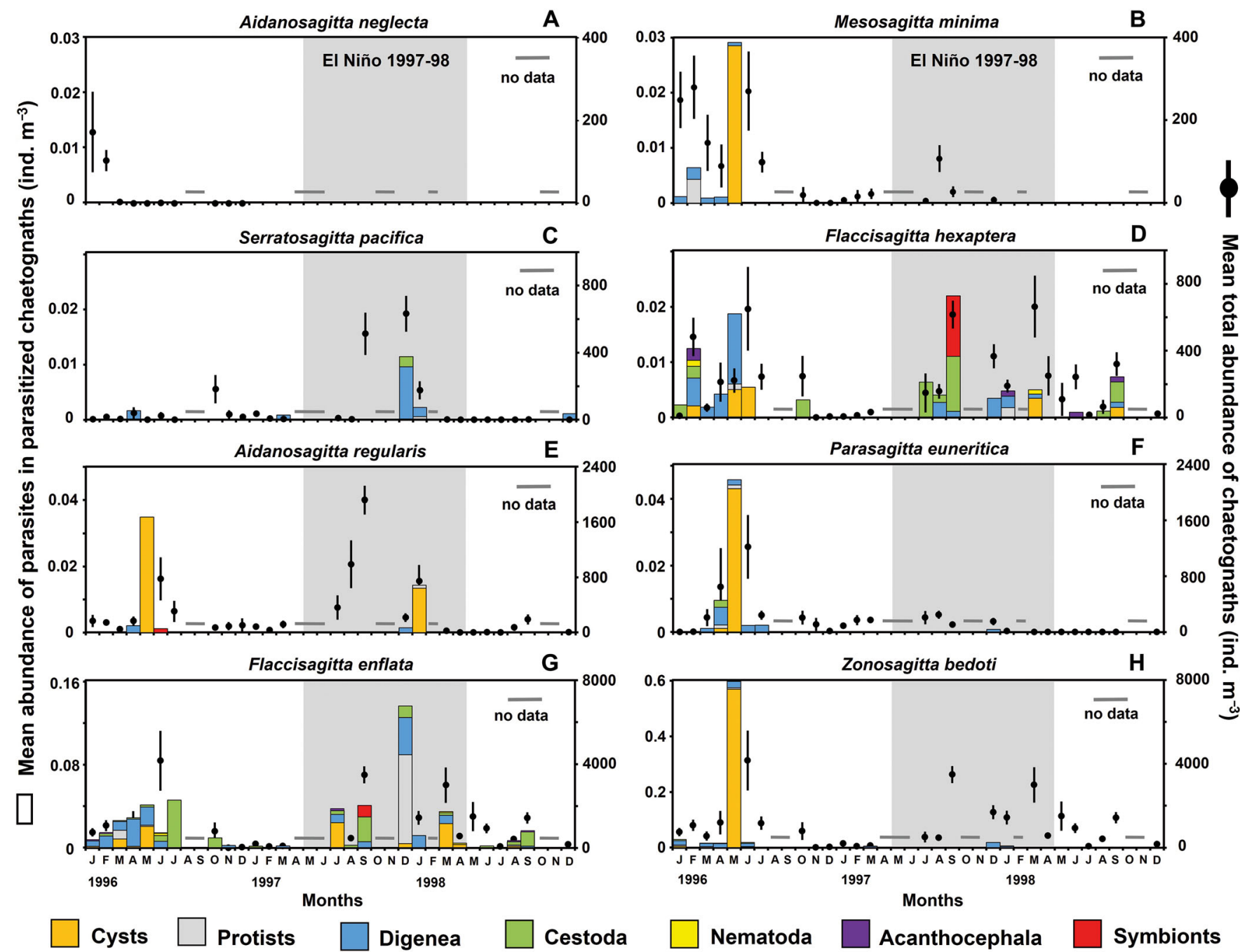

Drotists

Nematoda $\square$ Acanthocephala

Symbionts

Fig. 6. Temporal variability in standardized abundance of each type of parasite (cysts, protists, trematode Digenea, Cestoda, Nematoda, Acanthocephala, and non-identified symbionts) parasitizing each chaetognath species collected monthly during 1996-1998 along the continental shelf of the Mexican Central Pacific: (A) Aidanosagitta neglecta and Serratosagitta pseudoserratodentata were not observed parasitized (the latter is not shown here). (B) Mesosagitta minima. (C) S. pacifica. (D) Flaccisagitta hexaptera. (E) A. regularis. (F) Parasagitta euneritica. (G) F. enflata. (H) Zonosagitta bedoti (species ordered from minimum to maximum abundance)

December 1997 (Fig. 7D). The maximum species richness of parasitized chaetognaths $(n=6)$ was observed at Stn 10 during November 1997 (Fig. 7E). Usually 1 or 2 parasitized chaetognath species were observed per sampling station during the rest of the zooplankton time series (Fig. 7E). Parasite species richness was highest at Stns 9 and 11 (February 1996), 5 (May 1996), 3 and 5 (June 1996), 12 (December 1997), and 1 (January 1998) (Fig. 7F). Parasite type richness showed a more heterogeneous spatial and temporal distribution, with relatively high richness during January-July 1996 (near the coast) and during September 1997-January 1998 at stations of both sampling transects (Fig. 7D-F).
The highest abundances of parasitized chaetognaths and prevalence were observed during 1996 and the lowest during 1997, and the highest mean intensity was observed during 1998 (Table 2). Epibiont cysts were the most abundant and prevalent parasites infecting chaetognaths throughout the entire zooplankton time series, followed by protists, digeneans, and cestodes. Nematodes, acanthocephalans, and the other symbionts were observed in very low abundances, frequency, and prevalence. Protists were the parasites with the highest mean intensity observed in the present study, attaining their highest values during 1997 (Table 2). 


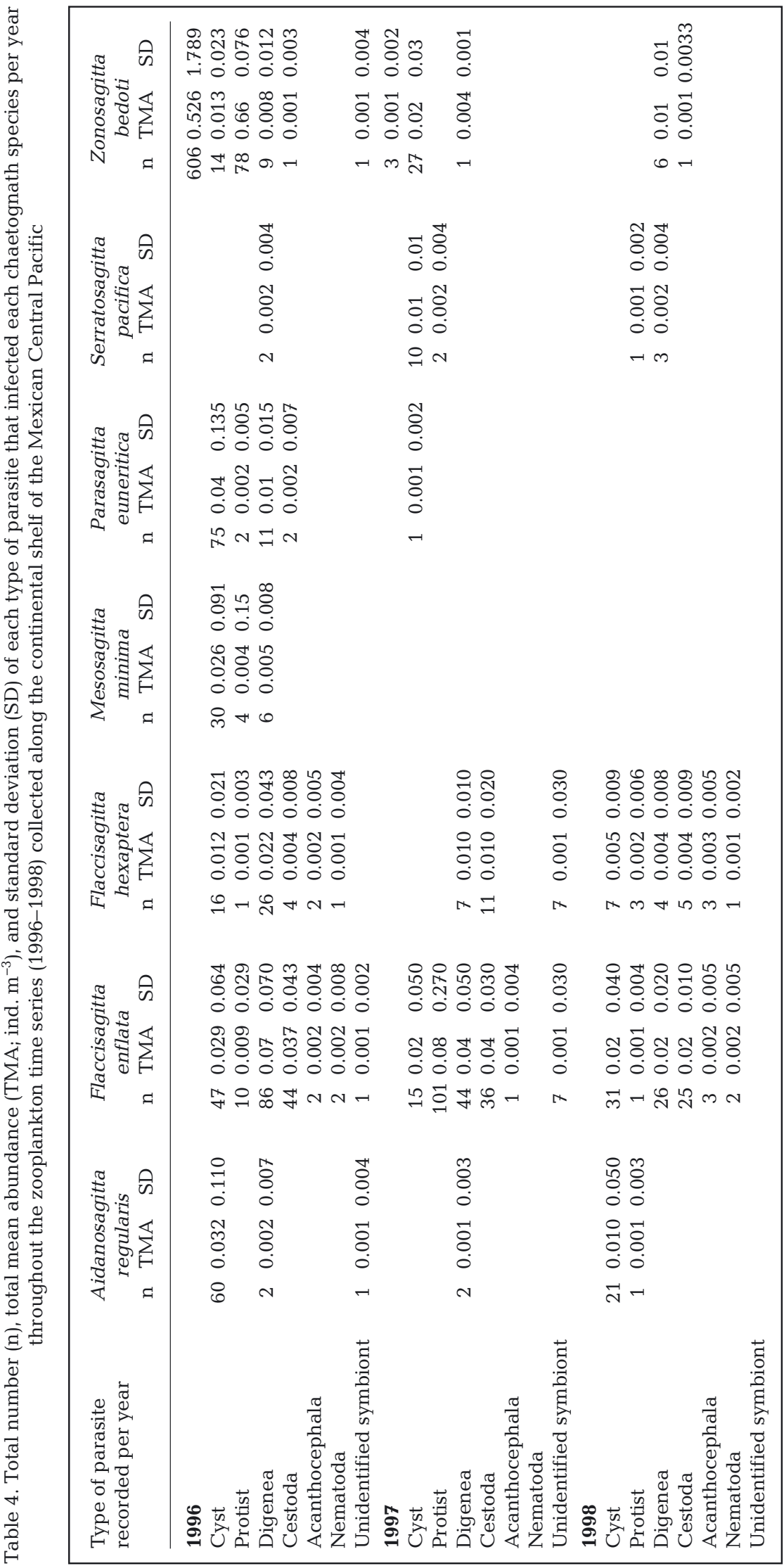

\section{Two-way cluster analysis}

A 2-way cluster analysis of mean abundance of chaetognath species assemblages as a function of monthly environmental variability (Table 5) showed 4 groups of sampling months at a cutoff of $65 \%$ of remaining information $\left(\mathrm{A}_{1}-\mathrm{A}_{4}\right)$ (Fig. 8A), and 3 groups of chaetognath species at a cutoff of $75 \%\left(\mathrm{~B}_{1}-\mathrm{B}_{3}\right)$ (Fig. 8B). The $\mathrm{B}_{2}$ cluster of chaetognath species had significantly larger chaetognath abundance than groups $\mathrm{B}_{1}$ and $\mathrm{B}_{3}(H=48, \mathrm{p}<0.01$, ANOVA Kruskal-Wallis rank test). Groups based on temporal variability were defined by a mix of climatic periods (Fig. 8A, Table 5). Group $\mathrm{A}_{1}$ included sampling months pre-El Niño 1997-1998 and during El Niño, including all the chaetognath species. Group $\mathrm{A}_{2}$ included sampling months prior to El Niño 1997-1998 and included all chaetognath species except $A$. neglecta and $S$. pseudoserratodentata. $\mathrm{A}_{3}$ included mixed months during and after El Niño 1997-1998 with 4 chaetognath species: $A$. regularis, $F$. enflata, $F$. hexaptera, and $Z$. bedoti. $\mathrm{A}_{4}$ had only 1 sampling month (July 1998) after El Niño and was numerically dominated by $F$. enflata and F. hexaptera (Fig. 8A). The chaetognath species were clustered in 3 groups $\left(\mathrm{B}_{1}-\mathrm{B}_{3}\right.$, Fig. $\left.8 \mathrm{~B}\right)$ : group $B_{1}$ included 2 species with low abundance: A. neglecta (JanuaryMarch 1996) and S. pseudoserratodentata (February 1996). $\mathrm{B}_{2}$ included the most abundant and frequent chaetognath species (A. regularis, $F$. enflata, $F$. hexaptera, $Z$. bedoti, $M$. minima, and P. euneritica) (Fig. 8B). $\mathrm{B}_{3}$ included only $S$. pacifica with medium abundance and low frequency, and in group $\mathrm{B}_{3}, S$. pacifica was absent between March and September 1998 (Fig. 8B).

The second 2-way cluster analysis of mean abundance of parasitized chaetognath species and the 7 types of parasites as a function of monthly environmental variability showed 4 groups of sampling months at a cutoff at $57 \%$ of 


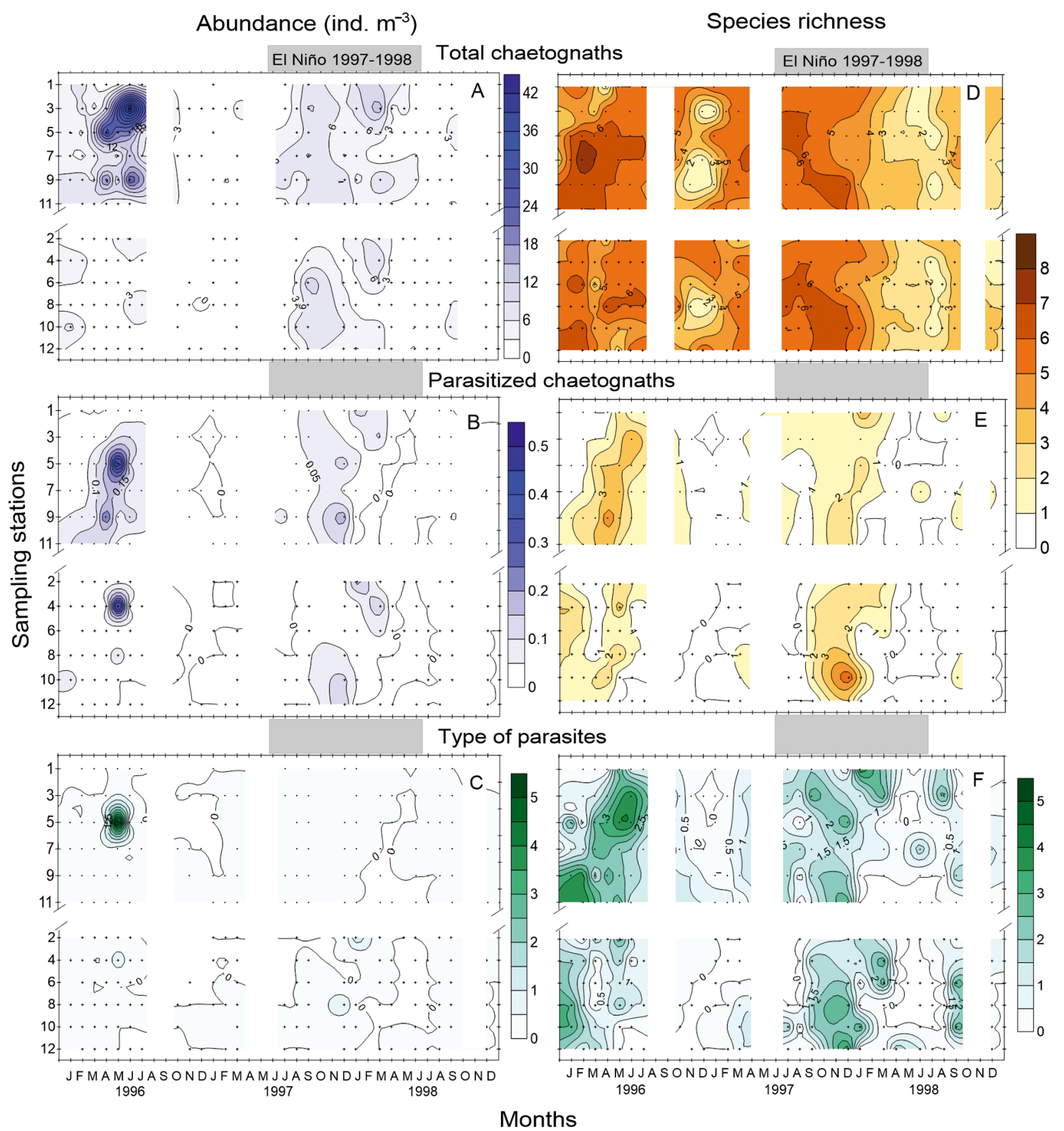

Fig. 7. Spatial and temporal distribution of $(A-C)$ abundance (ind. $\mathrm{m}^{-3}$ ) and (D-F) species richness of chaetognaths and their parasites collected monthly during 1996-1998 along the continental shelf of the Mexican Central Pacific separating the 2 sampling transects: one near the coast (Stations 1, 3, 5, 7, 9, and 11) and another farther from the coast (stations: 2, 4, 6, 8, 10, and 12). Abundance of all species combined of (A) chaetognaths, (B) parasitized chaetognaths, and (C) parasites. Species richness of all species combined of (D) chaetognaths, (E) parasitized chaetognaths, and (F) parasites

remaining information $\left(\mathrm{C}_{1}-\mathrm{C}_{4}\right.$; Fig. 8C, Table 6) and 6 groups of parasitized chaetognath species and their parasites at a cutoff of $75 \%\left(D_{1}-D_{6}\right)$ (Fig. 8D). These 4 groups of sampling months had significant differences among their abundances $(H=36.75, \mathrm{p}<0.0001$, ANOVA Kruskal-Wallis rank test). The sum of the rank of total abundance was significantly higher in group $\mathrm{C}_{1}$ than in any of the other 3 groups (MannWhitney $U$-test, $\mathrm{p}<0.005$ ), and the lowest abundance was recorded in groups $\mathrm{C}_{3}$ and $\mathrm{C}_{4}$ (no significant differences) (Mann-Whitney $U$-test, $\mathrm{p}<0.8856)$. All $\mathrm{C}$ groups of monthly variability, except $\mathrm{C}_{3}$ (with pre-El 
Table 5. Mean abundance (ind. $\mathrm{m}^{-3}$ ) and relative frequency (\%) of chaetognath species assemblages, and mean and range of environmental conditions per sampling group resulting from the 2-way cluster analysis. Groups are $\mathrm{A}_{1}$ : pre-El Niño and El Niño 1997-98 $(n=13), A_{2}$ : pre-El Niño $(n=5), A_{3}$ : mixed El Niño and post-El Niño $(n=6)$, and $A_{4}:$ post-El Niño (n = 1). N: 25 months (between January 1996 and December 1998), n: number of sampling months per group

\begin{tabular}{|c|c|c|c|c|c|c|c|c|}
\hline & \multicolumn{2}{|c|}{ Group $\mathrm{A}_{1}$} & \multicolumn{2}{|c|}{ Group $\mathrm{A}_{2}$} & \multicolumn{2}{|c|}{ Group $\mathrm{A}_{3}$} & \multicolumn{2}{|c|}{ Group $\mathrm{A}_{4}$} \\
\hline & Mean & $\%$ & Mean & $\%$ & Mean & $\%$ & Mean & $\%$ \\
\hline \multicolumn{9}{|l|}{$\begin{array}{l}\text { Abundance } \\
\text { (Chaetognath species) }\end{array}$} \\
\hline Aidanosagitta neglecta & 21.44 & 0.4 & & & & & & \\
\hline Aidanosagitta regularis & 458.83 & 9.6 & 85.25 & 9.5 & 47.72 & 1.9 & & \\
\hline Flaccisagitta enflata & 1389.52 & 29.0 & 80.23 & 8.9 & 1307.11 & 50.9 & 70.53 & 71.4 \\
\hline Flaccisagitta hexaptera & 277.14 & 5.8 & 11.53 & 1.3 & 274.89 & 10.7 & 15.22 & 15.4 \\
\hline Mesosagitta minima & 108.58 & 2.3 & 8.82 & 1.0 & & & & \\
\hline Parasagitta euneritica & 313.23 & 6.5 & 110.72 & 12.3 & & & & \\
\hline Serratosagitta pacifica & 122.85 & 2.6 & 18.55 & 2.1 & 0.28 & & & \\
\hline Serratosagitta pseudoserratodentata & 0.0001 & 0.1 & & & & & & \\
\hline Zonosagitta bedoti & 2092.11 & 43.7 & 581.71 & 64.9 & 935.64 & 36.5 & 13.01 & 13.2 \\
\hline Environmental conditions & Mean & Range & Mean & Range & Mean & Range & Mean & Range \\
\hline Thermal stratification index (TSI) & 10.1 & $4.67-14.97$ & 11.2 & $8.21-14.24$ & 10.5 & $7.36-14.27$ & 9.5 & - \\
\hline Temperature at $10 \mathrm{~m}\left(\mathrm{~T}_{10 \mathrm{~m}}\right)$ & 26.9 & $21.43-30.75$ & 25.6 & $22.45-28.17$ & 27.4 & $23.02-30.36$ & 29.3 & - \\
\hline Salinity at $10 \mathrm{~m}\left(\mathrm{~S}_{10 \mathrm{~m}}\right)$ & 34.1 & $33.33-34.74$ & 34.2 & $33.86-34.62$ & 34.1 & $33.61-34.47$ & 34.3 & - \\
\hline Mixed layer depth (MLD) & 51.6 & $18.0-90.0$ & 37.6 & $35.50-40.0$ & 30.8 & $19.0-43.0$ & 43.0 & - \\
\hline Coastal upwelling index (CUI) & 120.4 & $0.0-307.0$ & 100.0 & $47.0-162.0$ & 240.8 & $44.0-472.0$ & 50.0 & - \\
\hline CUI on sampling day (CUI sam $)$ & 110.6 & $38.0-230.0$ & 53.8 & $19.0-92.0$ & 116.0 & $63.0-276.0$ & 53.0 & - \\
\hline CUI 8 d before sampling ( $\left.\mathrm{CUI}_{\mathrm{sam}-8}\right)$ & 57.2 & $0.0-142.0$ & 58.2 & $22.0-111.0$ & 88.8 & $15.0-277.0$ & 24.0 & - \\
\hline
\end{tabular}

Niño conditions), mixed several periods of environmental conditions (Fig. 8C). Group $\mathrm{C}_{1}$ included months sampled before and during El Niño 19971998. All 7 parasitized chaetognath species and the 7 types of parasites were included in group $\mathrm{C}_{1}$. Group $\mathrm{C}_{2}$ was a mix of pre-El Niño, El Niño 1997-1998 and post-El Niño periods featuring the exclusive presence of $F$. enflata and $F$. hexaptera with all types of parasites (Fig. 8C, Table 6). Group $\mathrm{C}_{3}$ was a small group of months sampled exclusively during the preEl Niño period (November 1996 and February 1997), with very low abundance and low frequency of $F$. enflata parasitized by Digenea (Fig. 8C, Table 6). $\mathrm{C}_{4}$ included months from 2 periods, pre- and post-El Niño, with low abundance and frequency of $F$. enflata parasitized by Cestoda. The parasitized chaetognath species and parasite assemblages were clustered in the following 6 groups at a cutoff of $75 \%$ (Fig. 8D): Group $\mathrm{D}_{1}$ included $A$. regularis, $M$. minima, and $P$. euneritica with epibiont cysts; group $\mathrm{D}_{2}$ clustered $F$. enflata, $F$. hexaptera, and $Z$. bedoti associated with Cestoda and Digenea. Group $\mathrm{D}_{3}$ included only $S$. pacifica and protists. $\mathrm{D}_{4}$ included $F$. enflata, $F$. hexaptera, and $Z$. bedoti parasitized exclusively by Acanthocephala (January 1996, July 1997, and February and September 1998). $\mathrm{D}_{5}$ included $F$. enflata, $F$. hexaptera, $Z$. bedoti, and $S$. pacifica chaetognaths infected with $\mathrm{Ne}$ matoda (June 1996, March and April 1998). $D_{6}$ in- cluded only parasitized chaetognaths ( $F$. enflata, $F$. hexaptera, $Z$. bedoti, and S. pacifica) with unidentified symbionts (June 1996 and September 1997) (Fig. 8D).

\section{NMDS}

The coefficient of determination of correlations between ordination distances and distances in the original $\mathrm{n}$-dimensional spaces in the community structure of 9 chaetognath species was 0.238 for the first axis and 0.661 for the second axis. Both axes explained $\sim 90 \%$ of the total variability of the community structure of chaetognath species with a stress of 5.74 (Table S3A). The first axis showed a negative correlation with the abundance of all chaetognath species except $S$. pacifica, $P$. euneritica, and $A$. regularis (Fig. 9A, Table S3A). Mean abundances of these 3 chaetognath species occurred when the TSI was high and when the mixed layer was deep before and during El Niño 1997-1998. F. enflata, $F$. hexaptera, and $Z$. bedoti were close to the center of the NMDS because they were present during most of the study period, and M. minima was closely associated with low temperature. A. neglecta and $S$. pseudoserratodentata were relatively abundant at high salinity $\left(\mathrm{S}_{10 \mathrm{~m}}\right)$ values and high values of all upwelling indexes tested during the pre-El Niño 


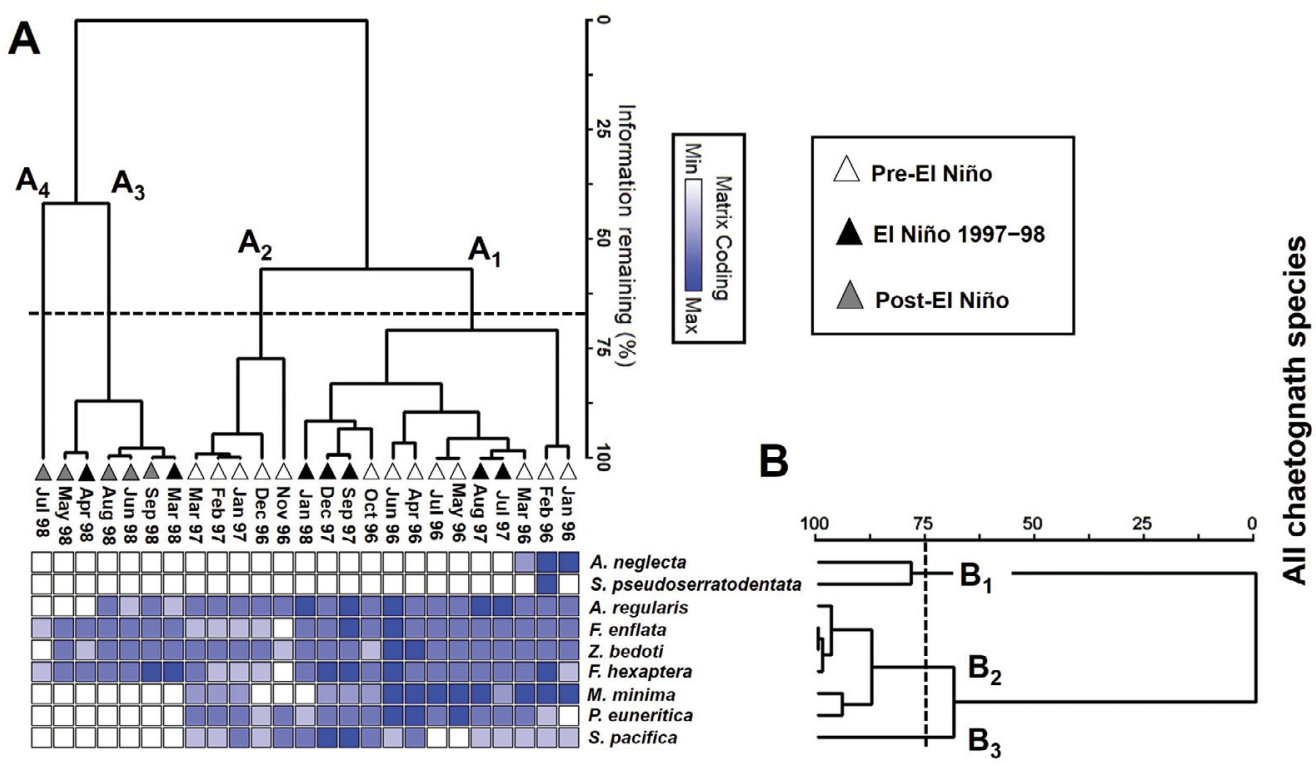

Fig. 8. Two-way cluster analysis of the temporal changes of (A) sampling stations (cutoff of $60 \%$ of remaining information, forming 4 groups: $\mathrm{A}_{1}-\mathrm{A}_{4}$ ) and (B) mean abundance of all 9 chaetognath species (cutoff of $75 \%$, forming 3 groups: $\left.\mathrm{B}_{1}-\mathrm{B}_{3}\right)$. Another 2-way cluster analysis of the temporal change of (C) sampling stations (cutoff of $57 \%$, forming 4 groups: $\mathrm{C}_{1}-\mathrm{C}_{4}$ ) and (D) mean abundance of 7 parasitized chaetognath species and their 7 types of parasites (cutoff of $75 \%$, forming 6 groups:

$$
\left.\mathrm{D}_{1}-\mathrm{D}_{6}\right)
$$
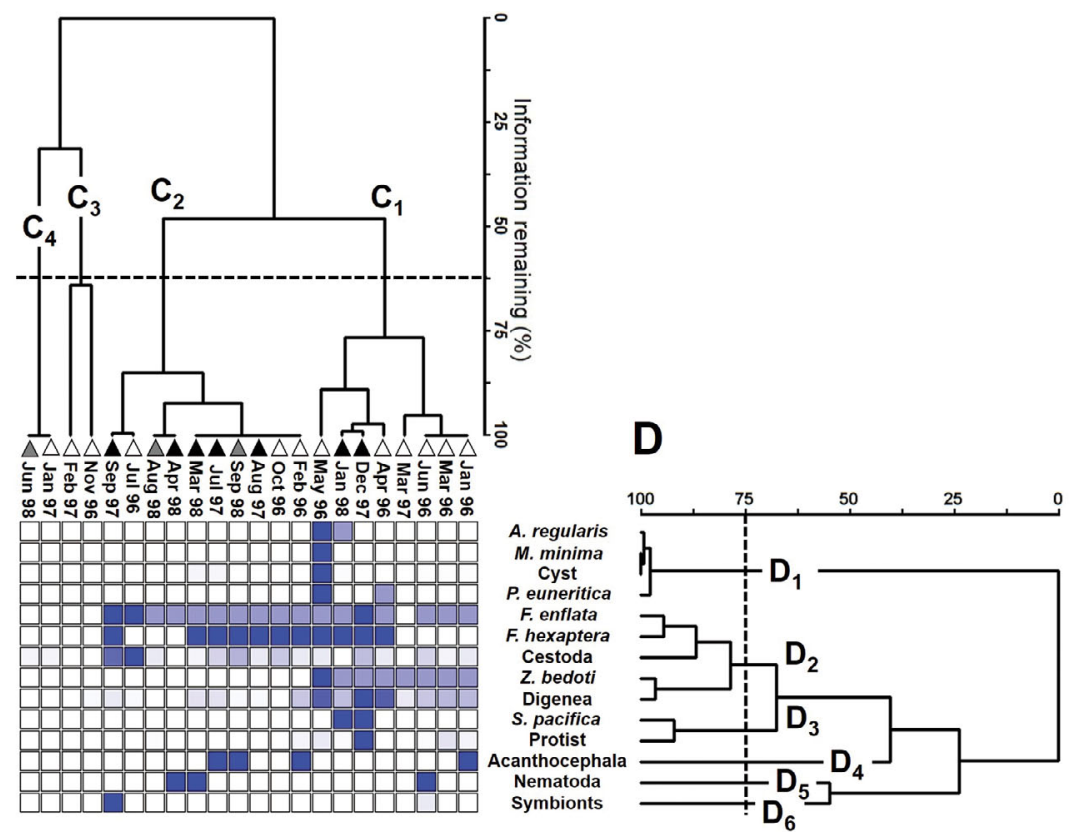

period. The second axis showed a small positive correlation with monthly CUI and a negative correlation with MLD. All chaetognath species were positioned in the negative section along the second axis, associated with large MLD and low CUI conditions (Fig. 9A, Table S3A).

In the second NMDS, the coefficient of determination of correlations between ordination distances and distances in the original n-dimensional spaces of the parasitized chaetognath species and their parasites was 0.312 for the first axis and 0.505 for the second axis. Both axes explained $~ 82 \%$ of the total variability of parasitized chaetognath species and their parasites (Table S3B). The Cestoda, Acanthocephala, and
Nematoda had a negative correlation with axis 1 , associated with high salinity and CUI values and with low parasite prevalence. The rest of the parasitized chaetognaths and parasites were positively correlated with MLD, TSI, and high parasite prevalence during the pre-El Niño and El Niño periods (Fig. 9B, Table S3B). The second axis showed a positive correlation of M. minima, $P$. euneritica, A. regularis, and $Z$. bedoti parasitized with cysts, protists, and Digenea, associated with high values of prevalence, salinity and $\mathrm{CUI}_{\mathrm{sam}-8}$. F. enflata, Cestoda, Acanthocephala, and unidentified symbionts were associated with periods of high temperature $\left(\mathrm{T}_{10 \mathrm{~m}}\right)$, MLD, and TSI (Fig. 9B, Table S3B). 
Table 6. Mean abundance (ind. $\mathrm{m}^{-3}$ ) and relative frequency $(\%)$ of parasitized chaetognath species and parasite assemblages, and mean and range of environmental conditions per group of sampling months resulting from the 2-way cluster analysis. Groups are $\mathrm{C}_{1}$ : before and during El Niño 1997-1998 $(\mathrm{n}=8), \mathrm{C}_{2}$ : a mix of pre-El Niño, El Niño $1997-1998$ and post-El Niño $(n=10), C_{3}$ : pre-El Niño $(n=2)$, and $C_{4}$ : post-El Niño $(n=2)$. N: 22 months (between January 1996 and December 1998), n: number of sampling months per group. Environmental conditions are defined in Table 5. Prevalence: percentage of parasitized chaetognaths per species from the total of each chaetognath species observed in the entire zooplankton sample

\begin{tabular}{|c|c|c|c|c|c|c|c|c|}
\hline & \multicolumn{2}{|c|}{ Group $\mathrm{C}_{1}$} & \multicolumn{2}{|c|}{ Group $\mathrm{C}_{2}$} & \multicolumn{2}{|c|}{ Group $\mathrm{C}_{3}$} & \multicolumn{2}{|c|}{ Group $\mathrm{C}_{4}$} \\
\hline & Mean & $\%$ & Mean & $\%$ & Mean & $\%$ & Mean & $\%$ \\
\hline \multicolumn{9}{|l|}{ Abundance } \\
\hline \multicolumn{9}{|c|}{ Parasitized chaetognath species } \\
\hline Aidanosagitta regularis & 6.87 & 10.9 & & & & & & \\
\hline Flaccisagitta enflata & 17.07 & 27.2 & 15.90 & 74.0 & 0.98 & 51.9 & 1.32 & 73.5 \\
\hline Flaccisagitta hexaptera & 3.26 & 5.2 & 4.67 & 21.7 & & & 0.48 & 26.5 \\
\hline Mesosagitta minima & 4.61 & 7.3 & 0.11 & 0.5 & & & & \\
\hline Parasagitta euneritica & 7.23 & 11.5 & 0.37 & 1.7 & & & & \\
\hline Serratosagitta pacifica & 1.85 & 2.9 & & & & & & \\
\hline Zonosagitta bedoti & 21.92 & 34.9 & 0.46 & 2.1 & 0.91 & 48.1 & & \\
\hline \multicolumn{9}{|l|}{ Parasites } \\
\hline Cysts & 0.093 & 63.1 & 0.006 & 20.5 & 0.001 & 48.1 & & \\
\hline Protists & 0.015 & 10.0 & 0.001 & 2.0 & & & & \\
\hline Digenea & 0.034 & 23.1 & 0.005 & 18.2 & 0.001 & 51.9 & & \\
\hline Cestoda & 0.005 & 3.2 & 0.013 & 47.1 & & & 0.001 & 75.7 \\
\hline Acanthocephala & 0.0005 & 0.3 & 0.001 & 3.0 & & & 0.0005 & 24.3 \\
\hline Nematoda & 0.0003 & 0.2 & 0.0004 & 1.5 & & & & \\
\hline Unidentified symbionts & 0.0002 & 0.2 & 0.002 & 7.7 & & & & \\
\hline Environmental conditions & Mean & Range & Mean & Range & Mean & Range & Mean & Range \\
\hline Prevalence (P) & 1.95 & $0.26-9.20$ & 0.56 & $0.09-1.24$ & 0.26 & $0.20-0.31$ & 0.06 & $0.05-0.07$ \\
\hline TSI & 9.05 & $4.67-13.10$ & 11.31 & $7.36-14.97$ & 11.23 & $8.21-14.24$ & 10.32 & $9.76-10.88$ \\
\hline $\mathrm{T}_{10 \mathrm{~m}}$ & 25.16 & $21.43-28.78$ & 28.15 & $23.01-30.75$ & 25.31 & $22.45-28.17$ & 27.71 & $26.13-29.29$ \\
\hline $\mathrm{S}_{10 \mathrm{~m}}$ & 34.20 & $33.34-34.74$ & 33.97 & $33.40-34.42$ & 34.24 & $33.86-34.62$ & 34.11 & $33.97-34.25$ \\
\hline MLD & 42.99 & 18.0-90.0 & 48.70 & 19.0-90.0 & 37.25 & $36.0-38.50$ & 40.0 & $38.0-42.0$ \\
\hline CUI & 162.50 & $60.0-307.0$ & 129.70 & $0.0-472.0$ & 104.50 & $47.0-162.0$ & 132.50 & $76.0-189.0$ \\
\hline $\mathrm{CUI}_{\mathrm{sam}}$ & 110.63 & $19.0-230.0$ & 106.30 & $44.0-276.0$ & 58.0 & $24.0-92.0$ & 64.50 & $52.0-77.0$ \\
\hline $\mathrm{CUI}_{\mathrm{sam}-8}$ & 65.38 & $13.0-127.0$ & 44.30 & $0.0-142.0$ & 66.50 & $22.0-111.0$ & 68.0 & $59.0-77.0$ \\
\hline
\end{tabular}

\section{MRPP}

The MRPP was used to statistically test the trends detected with the 2-way cluster analysis and NMDS analysis of community structure of chaetognaths, parasitized chaetognaths, and their types of parasites. We tested 4 null hypotheses (Table S4). The MRPP showed significant differences in the abundance of the chaetognath species assemblages among years $(1996,1997$, vs. 1998) $(p<0.01)$ and among monthly sampling groups separated by the 2-way cluster analysis $\left(\mathrm{A}_{1}-\mathrm{A}_{4}\right)(\mathrm{p}<0.01)$ (Table S4A). No significant difference was observed between chaetognath species assemblages and hydro-climatic periods or El Niño 1997-1998 vs. non El Niño periods (Table S4A). The MRPP also confirmed statistical differences in the abundances of parasitized chaetognath species and their parasite assemblages among the monthly sampling groups defined by the 2-way cluster analysis $\left(\mathrm{C}_{1}-\mathrm{C}_{4}\right)(\mathrm{p}<0.01)$ (Table S4B). No significant differences were observed in the other 3 hypotheses tested (Table S4B).

\section{ISA}

The ISA indicated that Mesosagitta minima was the only statistically significant chaetognath indicator of any of the hypotheses tested. This species was observed exclusively during the relatively cold 1996 period and in group $A_{1}$ (pre-El Niño 1997-1998) of the 2-way cluster analysis of the chaetognath species assemblages (Table S5A).

We also found that Cestoda were significant indicators of periods with water column stratified conditions when comparing the 3 hydro-climatic periods (Table S5B). Parasitized F. hexaptera and S. pacifica were significant indicators of El Niño 1997-1998 conditions (Table S5B). No parasitized host or parasite had a statistical difference in mean abundance 
among sampling years. The parasitized $Z$. bedoti and the Digenea parasites were significant indicators of group $\mathrm{A}_{1}$ (pre-El Niño and El Niño 1997-1998) defined by the 2-way cluster analysis and NMDS (Table S5B).

Overall, chaetognath abundance and diversity decreased after the 1997-1998 El Niño event, but parasite abundance did not change significantly throughout the zooplankton time series. Because overall mean prevalence was only $1 \%$, observed temporal variations in the abundances of the chaetognath hosts were not of large enough magnitude to show a detectable decrease in parasite abundances in the tropical coastal Mexican Central Pacific region.

\section{DISCUSSION}

The present study demonstrates that parasites of chaetognaths had a more heterogeneous distribution than their hosts, and that the parasite abundance was about $1 \%$ of their host abundances in the northern region of the Eastern Tropical Pacific. We also conclude that the El Niño 1997-1998 conditions, with anomalously high sea surface temperatures and low CUI, significantly decreased abundance and species richness of the chaetognaths (potential hosts) but had relatively little effect on the abundance and diversity of their parasites (relatively small density-dependent effect), because abundance of parasitized chaetognaths was considerably lower than total chaetognaths (mean 1\% prevalence). Therefore, changes in overall host population density do not seem to represent significant changes in host availability for parasite populations after a strong El Niño event. There are few zooplankton time series on parasites of chaetognaths, particularly in tropical latitudes (Lozano-Cobo et al. 2017a,b). Lozano-Cobo et al. (2017a) synthetized the available information of 5 zooplankton time series of parasites interacting with chaetognaths carried out in Russia, Canada, England, Japan, and Argentina
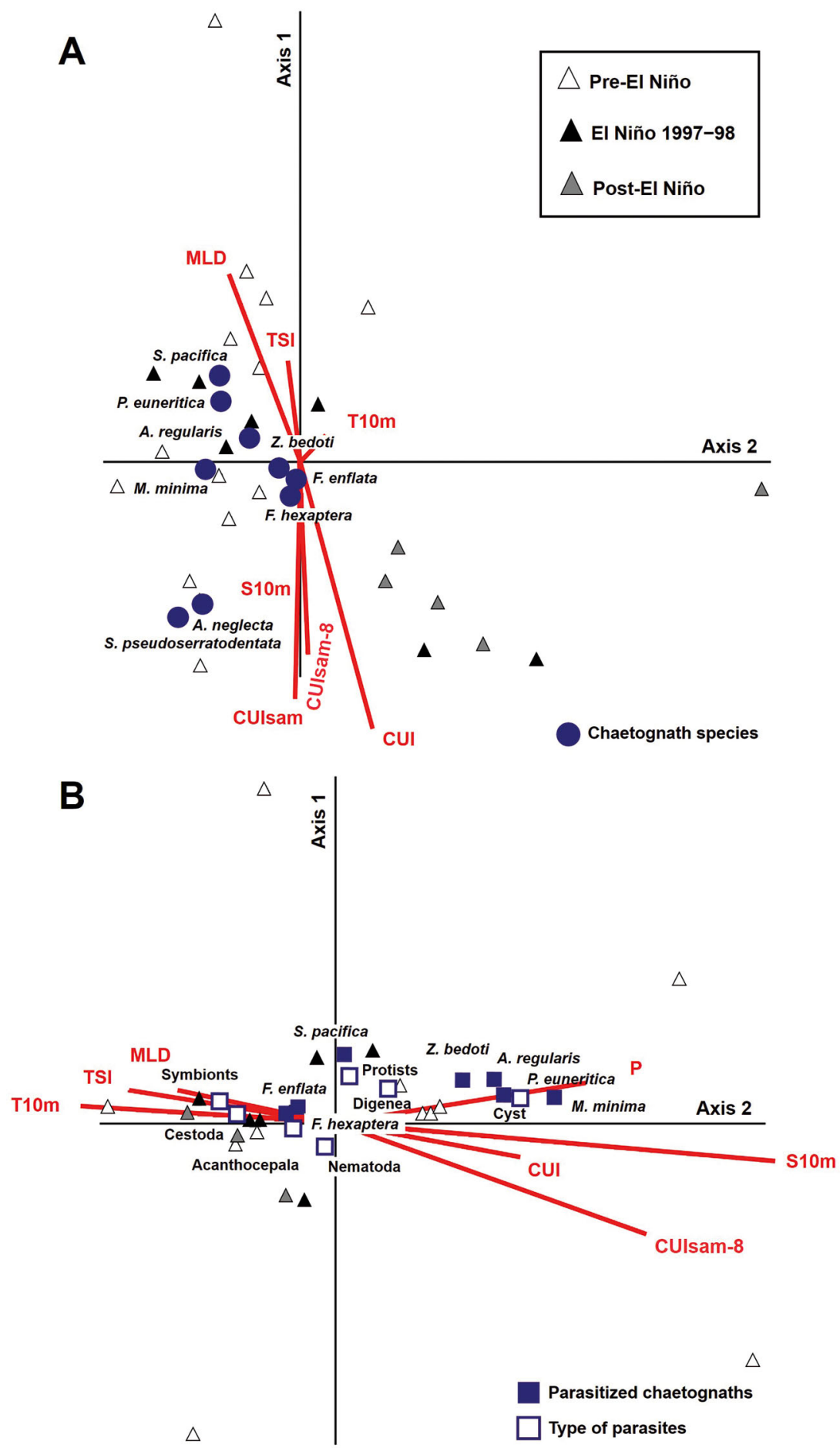

Fig. 9. Non-metric multi-dimensional scaling analyses of the relationship between (A) mean monthly abundance of all chaetognath species assemblages (9 species) and (B) parasitized chaetognath species ( 7 species) and 7 types of parasites as a function of the environmental conditions. TSI: thermal stratification index, T10 m: temperature at $10 \mathrm{~m}$ depth, S10m: salinity at $10 \mathrm{~m}$ depth, MLD: mixed layer depth, CUI: mean monthly coastal upwelling index, CUIsam $=$ daily CUI calculated on the day of the zooplankton sampling, CUIsam-8 = CUI calculated $8 \mathrm{~d}$ before each sampling event, P: prevalence (percentage of parasitized chaetognaths per species from the total of each chaetognath species observed in the entire zooplankton sample) 
(see their Table 1). Our study is the first systematic chaetognath time series that estimates the entire component community of parasites interacting with the chaetognath community in the Pacific Ocean. Ohtsuka et al. (2004) carried out a 1999-2000 zooplankton time series off Japan, but it was focused only on the apostome ciliate Vampyrophrya pelagica interacting with 3 chaetognath species. However, the present research is the third ecological study of parasitism in chaetognaths in the Mexican Pacific region, including the Gulf of California (Lozano-Cobo et al. 2012, 2017b, González-Solís \& Gasca 2018). GonzálezSolís \& Gasca (2018) only recorded the nematode Hysterothylacium sp. parasitizing a specimen of the bathypelagic chaetognath Heterokrohnia involucrum in the Alarcon Mount region in the Gulf of California.

\section{Density-dependent host-parasite interaction}

The chaetognath species diversity recorded during the 1996-1998 zooplankton time series was low (9 spp.), representing about $56 \%$ of the total 16 species known to be distributed in the Mexican Central Pacific, and only $26 \%$ of the 35 species reported for the entire Mexican Pacific coast (Franco-Gordo 2009, Franco-Gordo \& Plascencia-Palomera 2014). Chaetognath biogeography and abundance patterns in different water masses are relatively well known for the Northeast Pacific Ocean (Bieri 1959, Alvariño 1964, 1966, Brinton et al. 1986). Based on this biogeographic knowledge, we infer that Flaccisagitta enflata and $F$. hexaptera are numerically dominant cosmopolitan species, and Aidanosagitta regularis and Zonosagitta bedoti are 2 Indo-Pacific species. The less abundant species Mesosagitta minima is a cosmopolitan species, A. neglecta and Serratosagitta pacifica are Indo-Pacific species, and Parasagitta euneritica and $S$. pseudoserratodentata are endemic to the central North Pacific $\left(0-20^{\circ} \mathrm{N}\right)$, with highest abundances between $140^{\circ} \mathrm{E}$ and $130^{\circ} \mathrm{W}$ (Bieri 1959, Alvariño 1964, 1966). S. pseudoserratodentata represents only $1.3 \%$ of chaetognath abundance at Sagami Bay, Japan, leading Tokioka (1954) to conclude that chaetognaths from the Pacific Central Water mass penetrate in low abundance and temporal frequency into Sagami Bay throughout the year. The relative abundance of $S$. pseudoserratodentata during the 1996-1998 zooplankton time series in the Mexican Central Pacific region was very low $(<0.001 \%)$, making it highly unlikely to become parasitized in this tropical region. Thus, except for $A$. neglecta and $S$. pseudoserratodentata (due their low population den- sities, Table 3), 7 of the 9 chaetognath species (78\%) were parasitized with at least 1 of the 28 parasite or epibiont taxa. This is a large proportion of parasitized chaetognath species compared with the Caribbean Sea, where only 5 out 14 (36\%) chaetognath species were reported to be parasitized (Lozano-Cobo et al. 2017a). The overall chaetognath population abundance in the Mexican Central Pacific region $(0.22$ ind. $\mathrm{m}^{-3}$ maximum temporal abundance) was considerably smaller than that recorded at Laguna Nichupté (12 ind. $\mathrm{m}^{-3}$ maximum temporal abundance), but at a similar scale to the continental shelf of Yucatan Peninsula (0.32 ind. $\mathrm{m}^{-3}$ maximum temporal abundance) (Lozano-Cobo et al. 2017a). We report for the first time $A$. regularis, $M$. minima, and $S$. pacifica as parasite hosts in the Northeast Pacific (Table S1).

Host population density is one of the main factors controlling population density of parasites (Arneberg et al. 1998, Poulin 2007, Kamiya et al. 2014). We found a significant positive non-linear relationship between the mean abundance of chaetognaths (combining all species) and the mean abundance of parasites of chaetognaths in the Mexican Central Pacific region (Fig. 10A). We compared this density-dependent chaetognath-parasite relationship discovered in the Mexican Central Pacific with chaetognath and parasite abundances reported from 2 completely distinct ecosystems located in the Mexican Caribbean Sea: (1) Laguna Nichupté where Ferosagitta hispida accounts for $98 \%$ of 5 chaetognath species, attaining densities up to 12 ind. $\mathrm{m}^{-3}$, and (2) the Caribbean Sea continental shelf with a community of 12 chaetognath species recorded with relatively low population densities $<0.32$ ind. $\mathrm{m}^{-3}$ (Lozano-Cobo et al. 2017a). We tested this positive density-dependent hypothesis as the sum of all parasites in all parasitized chaetognath species (infracommunities) (Fig. 10A-C) and per type of parasite (epibiont cysts, microparasite protists, and symbionts) and macroparasite (metazoans) (data not shown). We conclude that chaetognaths and their parasite population densities have a significant positive, non-linear correlation independent of the ecosystem and local species richness (with distinct slope and intercept parameters). Overall, we observed that this correlation changes according to the chaetognath host abundance in each ecosystem. When the chaetognath community has typically low abundance $\left(<0.5\right.$ ind. $\left.\mathrm{m}^{-3}\right)$, this density-dependent relationship is a better fit to a polynomial regression model (Fig. 10A,C), and when chaetognaths have relatively high population densities, the relationship fits an exponential regression model (Fig. 10B). In the Mexican Central Pacific, parasites of chaetognaths had an overall prevalence of 


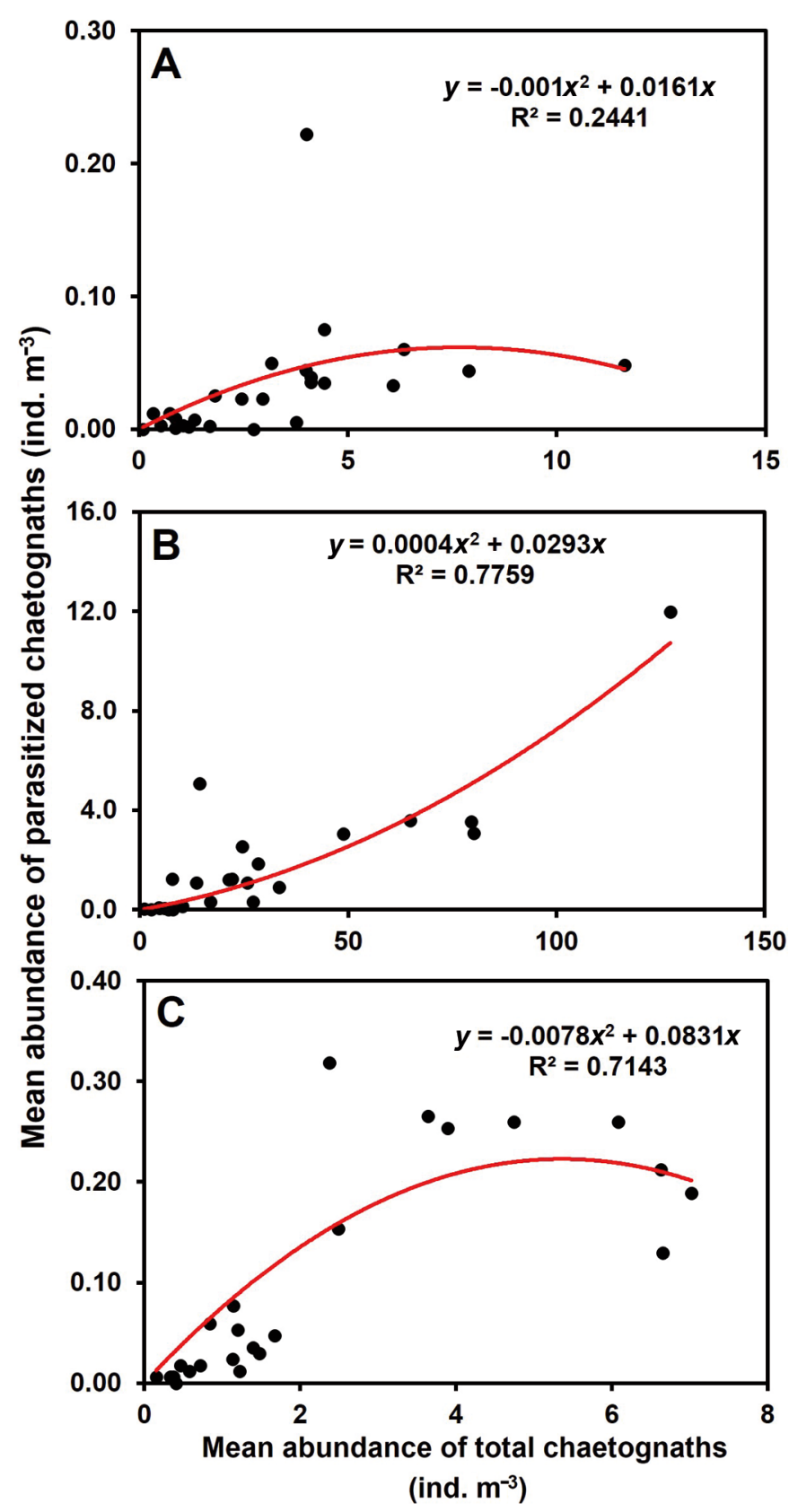

Fig. 10. Regression models of the relationship between the mean abundance of parasitized chaetognaths (all parasite taxa combined) and the mean abundance of total chaetognaths (all abundances were standardized to ind. $\mathrm{m}^{-3}$ ) in 3 distinct geographical regions: (A) Mexican Central Pacific (this study); (B) Laguna Nichupté, Yucatán peninsula; (C) continental shelf of the northeastern coast of Yucatan Peninsula, Mexico (Lozano-Cobo et al. 2017a)

$1 \%$ with relatively low host population densities (Lozano-Cobo et al. 2017b, this study), while in the Caribbean Sea, overall prevalence was $6 \%$, with densities up to 40 times greater in Laguna Nichupté than in the Mexican Central Pacific coast (Lozano-Cobo et al. 2017a) (Fig. 10A-C). The Mexican Central Pacific is a coastal region with a strong influence of windforced coastal upwelling and oceanic conditions due to the influence of water masses and seasonal circulation patterns of the tropical branch of the California Current, Mexican Coastal Current, and complex currents that prevail in the mouth of the Gulf of California (Filonov \& Tereschchenko 2000, Filonov et al. 2003, Godínez et al. 2010, Kurczyn et al. 2012, 2013, GómezValdivia et al. 2015, Portela et al. 2016). This region shows large temporal variability due the upwellingdownwelling dynamics that seasonally modify the abundance of the community structure of zooplankton (Franco-Gordo et al. 2004, 2015, Ambriz-Arreola et al. 2012, Gasca et al. 2012, Kozak et al. 2014). In contrast, the shallow (5 $\mathrm{m}$ depth) Laguna Nichutpé is part of the second largest coral reef system of the world (Puerto Morelos-Cancun), influenced by the Yucatan Current flows in poleward direction with a coastal countercurrent that flows toward the Equator (Álvarez-Cadena et al. 1998, Lozano-Cobo et al. 2017a). The estuarine and euryhaline conditions of the Laguna Nichupté decrease chaetognath diversity and favor a considerably high abundance of $F$. hispida (<140 ind. $\mathrm{m}^{-3}$ ), while a community with higher diversity but lower densities is dominated by $F$. enflata over the continental shelf of the Yucatan Peninsula (Álvarez-Cadena et al. 1996, Lozano-Cobo et al. 2017a). It is interesting that although considerable differences in chaetognathparasite diversity and abundance were observed between the Mexican Central Pacific (28 parasite taxa, this study) and the northeastern Yucatan Peninsula (33 taxa, Lozano-Cobo et al. 2017a), both regions showed significant positive density-dependent hostparasite interactions. The most notable differences in parasite taxa composition between these regions was the exclusive presence of the ectoparasite monogenean Gyrodactylus sp. in the Caribbean Sea (LozanoCobo et al. 2017a) and the discovery of the acanthocephalan Corynosoma sp. off the Mexican Central Pacific region (Lozano-Cobo et al. 2017b). The rest of the parasite component community was taxonomically similar for chaetognaths from both Mexican coasts. With the exception of monogeneans and acanthocephalans, the parasites observed in the present study have also been frequently found interacting with chaetognaths from other marine regions of the world (Reimer et al. 1971, Shimazu 1982, Jarling \& Kapp 1985, Mazzoni 1986, Gómez del Prado-Rosas et al. 2005, Øresland \& Bray 2005, Daponte et al. 2008, Almeida et al. 2009, Lozano-Cobo et al. 2017a,b). The present study reports the second most diverse parasite component community of chaetognaths worldwide, 
although the parasite abundance and prevalence recorded in the Mexican Central Pacific were comparatively lower than in the Caribbean Nichupté lagoon.

Most records of parasites of chaetognaths have been helminth larval stages, and depend on the size and swimming capabilities of the infected host. Chaetognaths most likely become infected while preying on small adult copepods (highly abundant) rather than larvae of euphausiids (which have a low probability of helminth infection) (Fig. 1B). Although Gómez-Gutiérrez et al. (2017) mentioned that endoparasite prevalence of euphausiids increases as the euphausiids develop and become larger, adult euphausiids are considerably less likely to be preyed on by chaetognaths. Marcogliese (2008) mentioned that trematodes are among the most common parasites of vertebrates, and here we demonstrated again that trematodes dominated (39\%) the component community of trophically transmitted parasites of chaetognaths (digenean trematodes, cestodes, nematodes, and acanthocephalans) (Fig. 1). Because chaetognaths are exclusively carnivores (and sometimes cannibals), we infer they are relevant intermediate or even accidental hosts in the trophic transmission of parasites to intermediate and definitive vertebrate hosts (Fig. 1A), as has been reported in other biogeographical regions of the world (Théodoridès 1989, Pierrot-Bults 1990, Nagasawa 1991, Gómez-del PradoRosas et al. 2005, Daponte et al. 2008, Lozano-Cobo et al. 2017a,b). The tegument of chaetognaths is thin, transparent, soft, and flaccid (Lozano-Cobo et al. 2017a), making them difficult to find in stomach contents of fish or any other vertebrates that prey on them. Flores-Ortega et al. (2010) reported that crustaceans, fishes, mollusks, polychaetes, and echinoderms are the main prey of 6 of the most abundant fish species in the Mexican Central Pacific (so far, no observational evidence that these predators prey on chaetognaths exists, because chaetognath hooks and teeth should remain in the guts of predatory fish). However, digenean trematodes (Hemiuridae, Parahemiurus sp., and Lepocreadiidae) have been found parasitizing chaetognaths (this study) and marine fishes of the Jalisco and Colima coasts (LamotheArgumedo et al. 1997, León-Règagnon et al. 1997, Pérez-Ponce de León et al. 2000), and the nematode Contracaecum sp. has been reported infecting marine fishes on the Nayarit coast (Lamothe-Argumedo et al. 1997). In order to more precisely define the function of chaetognaths in parasite transmission, morphological and molecular taxonomy studies are needed to identify the parasite species found in zooplankton, marine invertebrate (e.g. cephalopods), and marine vertebrate hosts (fishes, sharks, turtles, birds, and mammals), which would provide knowledge of the life cycle of each parasite reported in the Mexican Central Pacific (Fig. 1A,B). We did not observe parasites when the abundance of chaetognaths was $<0.1$ ind. $\mathrm{m}^{-3}$ (Fig. 10A-C), and infer that this is due to a kind of host-density threshold, where parasites have an extremely low probability of finding and infecting a chaetognath host (or that researchers will collect it). In ecological studies of parasitism, there is a minimum threshold of host abundance necessary for the development of chaetognath-parasite interactions in marine epipelagic communities. Therefore, our conclusion of a lower threshold of a direct densitydependent relationship between chaetognath hosts and parasites predicts that overall low prevalence will occur in biogeographical regions where chaetognaths typically have low abundances (i.e. oceanic populations in the Central Pacific) and the opposite in coastal ecosystems where chaetognaths typically have high population densities.

\section{Influence of El Niño 1997-1998 on chaetognath-parasite diversity}

Franco-Gordo et al. (2004) synthetized all zooplankton studies carried out during El Niño events in the Northeast Pacific and did not report any previous study of seasonal chaetognath community structure changes in the Eastern Tropical Pacific. Therefore, this is the first research to estimate the seasonal and interannual changes in abundance and prevalence of chaetognaths (and their parasites) as a function of environmental conditions, with particular interest in the effects caused by an El Niño event. El Niño 19971998 environmental conditions modified the community structure of chaetognaths (significantly decreasing their abundance and species diversity), causing less substantial changes in their component community of parasites (no significant differences). The statistical analysis of environmental conditions during the 1996-1998 zooplankton time series showed 2 distinct periods: (1) from January 1996-June 1998 with relatively high diversity and abundance of chaetognaths and parasites (a period that included El Niño 1997-1998 from June 1997-June 1998) and (2) from July-December 1998 with low diversity and abundance of chaetognaths (after El Niño 1997-1998). This relative decrease of chaetognath diversity and abundance after El Niño 1997-1998 was also recorded in fish larvae, amphipods, and copepods from 
the same zooplankton time series (Franco-Gordo et al. 2004, Gasca et al. 2012, Kozak et al. 2014). In contrast, species richness of euphausiids increased during El Niño, mostly due to the presence of oceanic species, but overall also showed a decreased abundance after El Niño 1997-1998 (Ambriz-Arreola et al. 2012). In the present study, 9 chaetognath species were found before El Niño 1997-1998 but only 7 of them were parasitized; during El Niño, 7 chaetognath species were found but only 6 were parasitized; and after El Niño, 4 chaetognath species found, but only 3 of them were parasitized. The decreased abundance of Mesosagitta minima and Parasagitta euneritica and the increased abundance of Aidanosagitta regularis and Serratosagitta pacifica were the main community changes as a consequence of El Niño 1997-98 environmental conditions. The first environmental signal of El Niño 1997-1998 in the region occurred during June 1997 when the seasonal strong winds increased upwelling activity between January and June 1998. However, because the MLD and the thermocline sank from 5-25 $\mathrm{m}$ before El Niño to 30-80 m after El Niño, subsurface upwelled water was not as cold as should be expected (see Fig. 2 of Ambriz-Arreola et al. 2012). Thus, the main environmental change of El Niño 1997-1998 was the increase of sea surface temperature, promoting pronounced changes in thermal stratification (homogeneously warm) and deepening of the MLD to 30$80 \mathrm{~m}$ depth. These thermal changes were caused by strong onshore advection of the Tropical Surface Water and Pacific Equatorial Surface Water in the upper $90 \mathrm{~m}$ layer of the Mexican Central Pacific region (Filonov \& Tereschchenko 2000, Ambriz-Arreola et al. 2012). García-Díaz et al. (2008) reported a decrease in species diversity of chaetognaths during May-June 1998 (El Niño period) and proposed that Pterosagitta draco is an indicator species of El Niño conditions in the Pacific Colombian coast. Naranjo (2009) reported chaetognath species composition changes and a generalized decrease of the abundance of chaetognaths during the onset of El Niño 1997-1998 at La Libertad, Ecuador.

Because our investigation is the first ecological study that estimates the diversity and abundance of the component community of parasites of chaetognaths as a function of environmental conditions during an El Niño event, comparisons cannot be made with other regions of the world. Our results show no significant changes in the diversity and abundance of the component community of parasites of chaetognaths before, during, and after El Niño 1997-1998, with the exception of the protist cells and unidenti- fied symbionts that increased their prevalence, abundance, and intensity during El Niño 1997-1998. Only parasites of Serratosagitta pacifica, Flaccisagitta enflata, and $F$. hexaptera chaetognaths showed increased abundances during El Niño. Therefore, we conclude that El Niño 1997-1998 had a densitydependent effect on the abundance of chaetognath species, but a relatively minor effect on changes in their parasites due to their relatively low prevalence and because parasitized chaetognath abundance was $<1 \%$ of total chaetognath abundance. Thus, changes in host abundance smaller than a factor of 20 likely do not have a significant effect on parasite population densities.

Mouritsen \& Poulin (2002) and Marcogliese (2008) described some possible effects of the increase in temperature on marine parasites of mollusks, crustaceans, echinoderms, and fish hosts. For example, an increase in temperature causes the emergence of larval digeneans (cercariae) that infect mollusks as the first intermediate host (Fig. 1A) (Koprivnikar \& Poulin 2009). However, parasites may respond in a different way to such increased temperatures (Marcogliese 2008). Here we demonstrated that although El Niño 1997-1998 decreased the diversity and abundance of chaetognaths along the continental shelf of the tropical Mexican Central Pacific, their parasites only showed statistically significant changes in abundance between the times during and after El Niño 1997-1998. We propose that changes in the environmental conditions during El Niño events might modify host abundance and diversity of chaetognaths, but those changes are probably not large enough to cause a drastic change in host-parasite interactions and host availability. This indicates that if global warming continues to increase ocean temperatures, chaetognath abundance will likely decrease; however, based on the evidence obtained so far, it is unlikely to have a large negative effect on their trophically transmitted endoparasites.

Acknowledgements. The University of Guadalajara provided research funds. We thank Ariel Cruz-Villacorta (CIBNOR) for his technical help with the SEM observations. Consejo Nacional de Ciencia y Tecnología (CONACYT) (A140618), PIFI-IPN (SIP20110012), BEIFI-IPN (SIP20140 $497,20150113,20171275$ ) provided $\mathrm{PhD}$ financial support to H.L.C. Funding for zooplankton analysis was provided by SIP-IPN annual grants (20110012, 20120948, 20130224, 20140497, 20150113, 20160495, 20171275) and SEP-CONACyT Ciencia Básica 2012-01-178615, 2016-01-284201. C.F.G., I.A.A., and J.G.G. are SNI fellows, and J.G.G. is also a COFFA-IPN and EDI-IPN fellow. We thank Eva Kozak for English editorial help on an earlier version of the manuscript. 


\section{LITERATURE CITED}

Almeida FM, Barquete V, Pereira J Jr (2009) Progenetic metacercariae of Parahemiurus merus (Platyhelminthes, Digenea, Hemiuridae) infecting Parasagitta friderici (Chaetognatha) from Southern coast Brazil. Atlântica 31: 35-38

Álvarez-Cadena JN, Suárez-Morales E, McLelland JA (1996) Observations on an isolated population of Sagitta hispida Conant (Chaetognatha) in a tropical lagoon system of Northeast Yucatán (Mexico). Gulf Res Rep 9: 197-204

Álvarez-Cadena JN, Suárez-Morales E，Gasca R (1998) Copepod assemblages from a reef related environment in the Mexican Caribbean Sea. Crustaceana 71:411-432

Alvariño A (1963) Quetognatos epiplanctónicos del Mar de Cortés. Rev Soc Mex Hist Nat 24:97-203

Alvariño A (1964) Bathymetric distribution of chaetognaths. Pac Sci 18:64-82

Alvariño A (1965) Chaetognaths. Oceanogr Mar Biol Annu Rev 3:115-195

Alvariño A (1966) Zoogeografía de California: quetognatos. Rev Soc Mex Hist Nat 27:200-243

Ambriz-Arreola I, Gómez-Gutiérrez J, Franco-Gordo MC, Lavaniegos BE, Godínez-Domínguez E (2012) Influence of coastal upwelling-downwelling variability on tropical euphausiid abundance and community structure in the inshore Mexican central Pacific. Mar Ecol Prog Ser 451: 119-136

Anderson RC, Chabaud AG, Willmott S (1975) Keys to the nematode parasites of vertebrates. Commonwealth Agricultural Bureaux International, Farnham Royal

Arneberg P, Skorping A, Grenfell B, Read AF (1998) Host densities as determinants of abundance in parasite communities. Proc R Soc B 265:1283-1289

Bieri R (1959) The distribution of the planktonic Chaetognatha in the Pacific and their relationship to the water masses. Limnol Oceanogr 4:1-28

Bieri R (1991a) Systematics of the Chaetognatha. In: Bone Q, Kapp H, Pierrot-Bults AC (eds) The biology of chaetognaths. Oxford Science Publications, New York, NY, p 122-136

Bieri R (1991b) Six new genera in the chaetognath family Sagittidae. Gulf Res Rep 8:221-225

Bray RA (2005) 45 Family Lepocreadiidae Odhner, 1905. In: Jones A, Bray RA, Gibson DI (eds) Keys to the Trematoda, Vol 2. CAB International and Natural History Museum, London, p 545-602

Bray RA, Gibson DI, Jones A (2008) Keys to the trematode, Vol 3. CAB International and Natural History Museum, London

Brinton EA, Fleminger A, Siegel-Causey D (1986) The temperature and tropical planktonic biotas of the Gulf of California. Calif Coop Ocean Fish Invest Rep 27: 228-266

Bush AO, Lafferty KD, Lotz JM, Shostak AW (1997) Parasitology meets ecology on its own terms: Margolis et al. revisited. J Parasitol 83:575-583

Chabaud A (1975) CIH Keys to the nematode parasites of vertebrates. CAB International, Wallingford

Coats DW, Bachvaroff T, Handy SM, Kim S, Gárate-Lizárraga I, Delwiche CF (2008) Prevalence and phylogeny of parasitic dinoflagellates (Genus Blastodinium) infecting copepods in the Gulf of California. CICIMAR Oceánides 23:67-77
Daponte MC, Gil de Pertierra AA, Palmieri MA, Ostrowski de Nuñez M (2008) Monthly occurrence of parasites of the chaetognath Sagitta friderici off Mar del Plata, Argentina. J Plankton Res 30:567-576

* Dawes B (1959) On Cercaria owreae (Hutton, 1954) from Sagitta hexaptera (d'Orbigny) in the Caribbean plankton. J Helminthol 33:209-222

Dufrene M, Legendre P (1997) Species assemblages and indicator species: the need for a flexible asymmetrical approach. Ecol Monogr 67:345-366

Field JG, Clarke KR, Warwick RM (1982) A practical strategy for analysing multispecies distribution patterns. Mar Ecol Prog Ser 8:37-52

Filonov AE, Tereschchenko IE (2000) El Niño 1997-98, monitoring in mixed layer at the Pacific Ocean near Mexico's west coast. Geophys Res Lett 27:705-708

Filonov AE, Tereschchenko IE, Monzon CO (2003) Hydrographic monitoring of El Niño 1997-98 off the coast of southwest Mexico. Geofis Int 44:1-6

* Flores-Ortega JR, Godínez-Domínguez E, Rojo-Vázquez JA, Cargos A, Galván-Piña VH, González-Sansón G (2010) Interacciones tróficas de las seis especies de peces más abundantes en la pesquería artesanal en dos bahías del Pacífico Central Mexicano. Rev Biol Trop 58:383-397

Franco-Gordo C (2009) Base de datos y colección de distintos grupos del zooplancton de regiones marinas prioritarias de Jalisco y Colima en el Pacífico Mexicano. Version 1.3. Universidad de Guadalajara, Centro Universitario de la Costa Sur. Comisión Nacional para el Conocimiento y uso de la Biodiversidad. https://doi.org/ 10.15468/5qtvhh

Franco-Gordo C, Plascencia-Palomera V (2014) Quetognatos de la costa sur de Jalisco y Colima. En: FrancoGordo MC (ed) Inventario de biodiversidad de la costa sur de Jalisco y Colima. Universidad de Guadalajara, Guadalajara, p 1-100

Franco-Gordo C, Godínez-Domínguez E, Suárez-Morales E (2002) Larval fish assemblages in waters off the central Pacific coast of Mexico. J Plankton Res 24:775-784

* Franco-Gordo C, Godínez-Domínguez E, Suárez-Morales E, Vásquez-Yeomans L (2003) Diversity of ichthyoplankton in the central Mexican Pacific: a seasonal survey. Estuar Coast Shelf Sci 57:111-121

Franco-Gordo C, Godínez-Domínguez E, Filonov AE, Tereschchenko IE, Freire J (2004) Plankton biomass and larval fish abundance prior to and during the El Niño period of 1997-1998 along the central Pacific coast of Mexico. Prog Oceanogr 63:99-123

Franco-Gordo C, Ambriz-Arreola I, Kozak ER, GómezGutiérrez J, Plascencia-Palomera V, Godínez-Domínguez E, Hinojosa-Larios A (2015) Seasonal succession of zooplankton taxonomic group assemblages in surface waters of Bahía de Navidad, Mexico (November 2010December 2011). Hidrobiológica 25:335-345

García-Díaz XF, Gusmão LMO, Herrera Y (2008) Influencia de los eventos climáticos El Niño y La Niña en la comunidad de Chaetognatha de las aguas superficiales del Océano Pacífico Colombiano. Rev Bras Enga Pesca 3: $30-50$

* Gasca R, Franco-Gordo C, Godínez-Domínguez E, SuárezMorales E (2012) Hyperiid amphipod community in the Eastern Tropical Pacific before, during, and after El Niño 1997-1998. Mar Ecol Prog Ser 455:123-139

Gibson DI (2002a) 37 Family Hemiuridae Looss, 1899. In: Gibson DI, Jones A, Bray RA Keys to the Trematoda, Vol 
1. CAB International and Natural History Museum, London, p 305-340

Gibson DI (2002b) 38 Family Accacoeliidae Odhner, 1911. In: Gibson DI, Jones A, Bray RA (eds) Keys to the Trematoda, Vol 1. CAB International and Natural History Museum, London, p 341-347

Gibson DI, Jones A, Bray RA (eds) (2002) Keys to the Trematoda, Vol 1. CAB International and Natural History Museum, London

Godínez VM, Beier E, Lavin MF, Kurczyn A (2010) Circulation at the entrance of the Gulf of California from satellite altimeter and hydrographic observation. J Geophys Res 115:1-15

* Gómez del Prado-Rosas MC, Álvarez-Cadena JN, SeguraPuertas L, Lamothe-Argumedo R (1999a) First record of Torticaecum sp. (Trematoda: Didymozoidae) in the chaetognath Serratosagitta serratodentata (Krohn, 1853) from Caribbean waters. J Plankton Res 21:1005-1008

Gómez del Prado-Rosas MC, Álvarez-Cadena JN, SeguraPuertas L, Lamothe-Argumedo R (1999b) New records, hosts, and SEM observations of Cercaria owreae (Hutton, 1954) from the Mexican Caribbean Sea. J Helminthol Soc Wash 66:194-197

Gómez del Prado-Rosas MC, Álvarez-Cadena JN, SeguraPuertas L (2000) Metacercaria quintanarrooensis sp. nov. (Trematoda: Accacoeliidae) en Flaccisagitta enflata (Grassi, 1881) del Mar Caribe Mexicano. In: Rios-Jara E, Juárez-Carillo E, Pérez-Peña M, López-Uriarte E, Robles-Jarero EG, Hernández-Becerril DU, Silva-Briano M (eds) Estudios sobre plancton en México y el Caribe. Sociedad Mexicana de Planctología, Universidad de Guadalajara, p 31-32

* Gómez del Prado-Rosas MC, Álvarez-Cadena JN, SeguraPuertas L, Lamothe-Argumedo R (2002) An accacoeliid metacercaria parasitizing the arrow worm Flaccisagitta enflata (Grassi, 1881) from the Mexican Caribbean Sea. Comp Parasitol 69:108-111

* Gómez del Prado-Rosas MC, Álvarez-Cadena JN, SeguraPuertas L, Lamothe-Argumedo R (2005) Hemiurid metacercariae (Trematoda) in chaetognaths from the Mexican Caribbean Sea. Comp Parasitol 72:230-233

Gómez del Prado-Rosas MC, Álvarez-Cadena JN, SeguraPuertas L, Lamothe-Argumedo R (2007) Didymozoid trematode Monilicaecum type in chaetognaths from the Mexican Caribbean Sea. Rev Mex Biodivers 78:483-487

Gómez-Gutiérrez J, Kawaguchi S, Morales-Ávila JR (2017) Global diversity and ecological functions of parasites of euphausiids. Springer Nature, Cham

Gómez-Valdivia F, Pares-Sierra A, Flores-Morales A (2015) The Mexican coastal current: a subsurface seasonal bridge that connects the tropical and subtropical northeastern Pacific. Cont Shelf Res 110:100-107

González-Solís D, Gasca R (2018) First record of the bathypelagic chaetognath Heterokrohnia involucrum Dawson, 1968 in the Gulf of California and its association with a parasitic Nematode. Thalassas Int J Mar Sci 34:227-232

Jarling C, Kapp H (1985) Infestation of Atlantic chaetognaths with helminths and ciliates. Dis Aquat Org 1:23-28

Jones A, Bray RA, Gibson DI (eds) (2005) Keys to the Trematoda, Vol 2. CAB International and Natural History Museum, London

‘Kamiya T, O'Dwyer K, Nakagawa S, Poulin R (2014) What determines species richness of parasitic organisms? A meta-analysis across animal, plant and fungal hosts. Biol Rev Camb Philos Soc 89:123-134
Khalil LF, Jones A, Bray RA (eds) (1994) Keys to the cestode parasites of vertebrates. CAB International and Natural History Museum, London

Kondo Y, Ohtsuka S, Hirabayashi T, Okada S and others (2016) Seasonal changes in infection with trematode species utilizing jellyfish as hosts: evidence of transmission to definitive host fish via medusivory. Parasite 23:16

Koprivnikar J, Poulin R (2009) Effects of temperature, salinity, and water level on the emergence of marine cercariae. Parasitol Res 105:957-965

*Kozak ER, Franco-Gordo C, Suárez-Morales E, PalomaresGarcía R (2014) Seasonal and interanual variability of the calanoid copepod community structure in shelf waters of the Eastern Tropical Pacific. Mar Ecol Prog Ser 507: 95-110

Kurczyn JA, Beier E, Lavín MF, Chaigneau A (2012) Mesoscale eddies in the northeastern Pacific tropicalsubtropical transition zone: statistical characterization from satellite altimetry. J Geophys Res 117:C10021

Kurczyn JA, Beier E, Lavín MF, Chaigneau A, Gódinez VM (2013) Anatomy and evolution of a cyclonic mesoscale eddy observed in the northeastern Pacific tropical-subtropical transition zone. J Geophys Res Oceans 118: 5931-5950

Lamothe-Argumedo R, García-Prieto L, Osorio-Sarabia D, Pérez-Ponce de León G (1997) Catálogo de la Colección Nacional de Helmintos. Universidad Nacional Autónoma de México, Instituto de Biología, Comisión Nacional para el Conocimiento y uso de la Biodiversidad, Mexico City

Lavaniegos BE, Jiménez-Pérez LC, Gaxiola-Castro G (2002) Plankton response to El Niño 97-98 and La Niña 99 in the southern region of the California Current. Prog Oceanogr 54:33-58

Lavaniegos BE, García-García P, Hernández-León JC, López-Sánchez D, Poncela-Rodríguez L, Mejía-Acosta S (2006) Biomasa y estructura del zooplancton frente a la costa occidental de Baja California durante 2003 (Cruceros IMECOCAL 0302, 0304, 0307, 0310). Rep 47003, Departamento de Oceanografía Biológica, Centro de Investigación Científica y de Educación Superior de Ensenada

León-Règagnon V, Pérez-Ponce de León G, LamotheArgumedo R (1997) Hemiuriformes de peces marinos de la Bahía de Chamela, México, con la descripción de una nueva especie del género Hysterolecitha (Digenea: Hemiuridae: Lecithasterinae). An Inst Biol Univ Nac Auton Mex Ser Zool 68:1-34

Lozano-Cobo H, Gómez del Prado-Rosas MC, Cota-Meza MS, Pacheco-Chávez M, Sánchez-Velasco L (2012) Helmintos parásitos en quetognatos en el Alto Golfo de California, México. Biologist (Lima), Biologia y ecología de infecciones parasitarias 10(Suppl 2):32

*Lozano-Cobo H, Gómez del Prado-Rosas MC, SánchezVelasco L, Gómez-Gutiérrez J (2017a) Seasonal variation in chaetognath and parasite species assemblages along the northeastern coast of the Yucatan Peninsula. Dis Aquat Org 124:55-75

* Lozano-Cobo H, Gómez-Gutiérrez J, Franco-Gordo MC, Gómez del Prado-Rosas MC (2017b) The discovery of acanthocephalans parasitizing chaetognaths. Acta Parasitol 62:401-411

Marcogliese DJ (2008) The impact of climate change on the parasites and infectious diseases of aquatic animals. Rev Sci Tech Off Int Epizoot 27:467-484 
Mazzoni HE (1986) Chaetognath infested with larvae of Contracaecum sp. (Nematoda, Anisakidae) in the Argentine Sea. Physis Secc A 44:8-20

McCune B, Grace J, Urban D (2002) Analysis of ecological communities. MjM Software Design. Gleneden Beach, OR

Morales-Ávila JR, Gómez-Gutiérrez J, Gómez del PradoRosas MC, Robinson CJ (2015) Larval trematodes Paronatrema mantae and Copiatestes sp. parasitize Gulf of California krill (Nyctiphanes simplex, Nematoscelis difficilis). Dis Aquat Org 116:23-35

Mouritsen KN, Poulin R (2002) Parasitism, climate oscillations and the structure of natural communities. Oikos 97: $462-468$

Nagasawa S (1991) Parasitism and diseases in chaetognaths. In: Bone Q, Kapp H, Pierrot-Bults AC (eds) The biology of chaetognaths. Oxford Science Publications, New York, NY, p 76-85

Naranjo C (2009) Variaciones temporales del Phylum Quetognatos en las estaciones fijas la Libertad y Manta, Ecuador durante el evento El Niño 1997-1998 y años 2002-2003. Acta Oceanogr Pac 15:67-96

Ohtsuka S, Hora M, Suzaki T, Arikawa M, Omura G, Yamada K (2004) Morphology and host-specificity of the apostome ciliate Vampyrophrya pelagica infecting pelagic copepods in the Seto Inland Sea, Japan. Mar Ecol Prog Ser 282:129-142

* Øresland V, Bray RA (2005) Parasites and headless chaetognaths in the Indian Ocean. Mar Biol 147:725-734

Palma S, Aravena G (2002) Distribución estacional y vertical de los quetognatos capturados entre el Golfo Corcovado y el estero Elefantes. Cienc Tecnol Mar 25:87-104

Pérez-Ponce de León G, García-Prieto L, Rosas-Villa C (2000) Helmintofauna de Opisthonema libertate y Harengula thrissina (Osteichthyes: Clupeidae) de la bahía de Chamela, Jalisco, México. Rev Biol Trop 48:759-763

Pierrot-Bults AC (1990) Diseases of chaetognatha. In: Kinne O (ed) Diseases of marine animals, Vol III. Biologische Anstalt Helgoland, p 425-437

Portela E, Beier E, Barton ED, Castro R and others (2016) Water masses and circulation in the tropical Pacific off central Mexico and surrounding areas. J Phys Oceanogr 46:3069-3081

Poulin R (2007) Are there general laws in parasite ecology? Parasitology 134:763-776

Reimer LW, Berger C, Hewer B, Lainka H, Rosenthal I, Scharnweber L (1971) On the distribution of larvae of helminths in plankton animals of the North Sea. Parazitologiya 5:542-550

Editorial responsibility: Stephen Feist, Weymouth, UK
Rosenberg E, Sharon G, Atad I, Zilber-Rosenberg I (2010) The evolution of animals and plants via symbiosis with microorganisms. Environ Microbiol Rep 2:500-506

Salgado-Maldonado G (1979) Procedimientos y técnicas generales empleados en los estudios helmintológicos. Laboratorio de Helmintología, Oficina de Sanidad, Nutrición y Genética, Dirección General de Acuacultura, Departamento de Pesca, Mexico City

Shimazu T (1978) Some helminth parasites of the Chaetognatha from Suruga Bay, central Japan. Bull Natl Sci Mus (Jpn) A 4:105-116

Shimazu T (1982) Some helminth parasites of marine plankton invertebrates. J Naganoken Junior Coll 37:11-29

Smith P, Richardson S (1977) Standard techniques for pelagic fish egg and larva surveys. Fish Tech Pap 175. FAO, Rome

* Stanko M, Krasnov BR, Morand S (2006) Relationship between host abundance and parasite distribution: inferring regulating mechanisms from census data. J Anim Ecol 75:575-583

Ter Braak CJF (1986) Canonical correspondence analysis: a new eigenvector technique for multivariate direct gradient analysis. Ecology 67:1167-1169

Théodoridès J (1989) Parasitology of marine zooplankton. Adv Mar Biol 25:117-177

Tokioka T (1954) Droplets from the plankton net. Publ Seto Mar Biol Lab 3:359-368

Ulloa R, Palma S, Silva N (2000a) Bathymetric distribution of chaetognaths and their association with water masses off the coast of Valparaiso, Chile. Deep Sea Res I 47: 2009-2027

Ulloa R, Palma S, Linacre L, Silva N (2000b) Seasonal changes in the bathymetric distribution of siphonophores, chaetognaths and euphausiids associated to water masses off Valparaiso, Chile (Southeast Pacific). In: Färber JL (ed) Oceanography of the Eastern Pacific. CICESE, Ensenada, p 72-83

Weinstein M (1972) Studies on the relationship between Sagitta elegans Verrill and its endoparasites in the southwestern Gulf of St. Lawrence. PhD thesis, McGill University, Montreal

Yamaguti S (1959) Systema Helminthum. The cestodes of vertebrates, Vol II. Interscience Publishers, New York, NY

Yamaguti S (1961) Systema Helminthum. The nematodes of vertebrates, Vol III, Part. I. Interscience Publishers, New York, NY

Yamaguti S (1971) Synopsis of digenetic trematodes of vertebrates, Parts I and II. Keigaku Publishing, Tokyo

Submitted: December 18, 2017; Accepted: May 10, 2018

Proofs received from author(s): July 14, 2018 